\title{
Pharmacogenetics: data, concepts and tools to improve drug discovery and drug treatment
}

\author{
Jürgen Brockmöller • Mladen V. Tzvetkov
}

Received: 17 October 2007 / Accepted: 20 November 2007 / Published online: 26 January 2008

(C) The Author(s) 2008

\begin{abstract}
Variation in the human genome is a most important cause of variable response to drugs and other xenobiotics. Susceptibility to almost all diseases is determined to some extent by genetic variation. Driven by the advances in molecular biology, pharmacogenetics has evolved within the past 40 years from a niche discipline to a major driving force of clinical pharmacology, and it is currently one of the most actively pursued disciplines in applied biomedical research in general. Nowadays we can assess more than $1,000,000$ polymorphisms or the expression of more than 25,000 genes in each participant of a clinical study - at affordable costs. This has not yet significantly changed common therapeutic practices, but a number of physicians are starting to consider polymorphisms, such as those in CYP2C9, CYP2C19, CYP2D6, TPMT and VKORC1, in daily medical practice. More obviously, pharmacogenetics has changed the practices and requirements in preclinical and clinical drug research; large clinical trials without a pharmacogenomic add-on appear to have become the minority. This review is about how the discipline of pharmacogenetics has evolved from the analysis of single proteins to current approaches involving the broad analyses of the entire genome and of all mRNA species or all metabolites and other approaches aimed at trying to understand the entire biological system. Pharma-
\end{abstract}

\footnotetext{
J. Brockmöller $\cdot$ M. V. Tzvetkov

Department of Clinical Pharmacology,

Georg August University Göttingen,

Göttingen, Germany

J. Brockmöller $(\bowtie)$

Abteilung Klinische Pharmakologie,

Georg-August-Universität Göttingen,

Robert-Koch-Str. 40,

37075 Göttingen, Germany

e-mail: jbrockm@gwdg.de
}

cogenetics and genomics are becoming substantially integrated fields of the profession of clinical pharmacology, and education in the relevant methods, knowledge and concepts form an indispensable part of the clinical pharmacology curriculum and the professional life of pharmacologists from early drug discovery to pharmacovigilance.

\section{Pharmacogenetics of large single gene effects and their clinical consequences}

The science of pharmacogenetics originated from the analysis of a few rare and sometimes serendipitously found extreme reactions (phenotypes) observed in some humans; these phenotypes were either inherited diseases or abnormal reactions to drugs or other environmental factors. In 2008, we are facing about 12 million single nucleotide polymorphisms in the human genome and a large amount of other types of genomic variation. The impact of inherited chemical individuality in metabolic enzymes has been well known for more than 100 years [1], and still, the essence of pharmacogenetics can be best illustrated with paradigmatic case examples introduced below that show how inherited variants in specific genes may impact reactions of human beings to drugs and other environmental factors. Thus, the first part of the review focuses on those polymorphisms having a strong and reproducibly confirmed impact in therapy with the drugs affected by the polymorphic proteins (Table 1).

Genetic variation in drug-metabolizing enzymes

Glucose 6 phosphate dehydrogenase

A deficiency in the enzyme glucose-6-phosphase dehydrogenase (G6PDH) was identified when about $10 \%$ of 
Table 1 Valid biomarkers: Pharmacogenetic polymorphisms with a consistently proven functional impact that should be regularly considered in drug development and in drug treatment

\begin{tabular}{|c|c|c|}
\hline Protein & Abbreviation & Selected substrates, ligands or drugs for which the polymorphism may be relevant \\
\hline $\begin{array}{l}\text { Glucose-6-phosphate } \\
\text { dehydrogenase }\end{array}$ & G6PDH & Many drugs generating electrophilic reactive metabolites in human cells \\
\hline Butyrylcholine esterase & $\mathrm{BCHE}$ & Mivacurium, procaine, succinylcholine, \\
\hline $\mathrm{N}$-acetyltransferase type 2 & NAT2 & Isoniazid, aromatic amines (occupational medicine and toxicology) \\
\hline Cytochrome P450 2D6 & CYP2D6 & $\begin{array}{l}\text { Amitriptyline, clomipramine, desipramine, doxepin, duloxetin, imipramine, nortriptyline, } \\
\text { trimipramine, paroxetin, venlafaxin; haloperidol, perphenazine; chlorpromazine, } \\
\text { perazine, promethazine, thioridazine, zyclopenthixol; aripiprazole, olanzapine; } \\
\text { amphetamine, atomoxetin; carvedilol, metoprolol, nebivolol, propranolol, timolol; } \\
\text { perhexiline; encainide, flecainide, mexilletine; ondansetron, tropisetron; codeine, } \\
\text { tramadol; tamoxifen }\end{array}$ \\
\hline Cytochrome P450 2C19 & CYP2C19 & $\begin{array}{l}\text { Omeprazole, esomeprazole, lansoprazole, pantoprazole, rabeprazole; voriconazole; } \\
\text { diazepam, alprazolam; amitriptyline, imipramine, doxepin; moclobemide; citalopram; } \\
\text { S-mephenytoin, phenytoin, primidone; clopidogrel; proguanil; cyclophosphamide, } \\
\text { teniposide }\end{array}$ \\
\hline Cytochrome P450 2C9 & CYP2C9 & $\begin{array}{l}\text { S-Warfarin, acenocoumarol, phenprocoumon; glimepiride, tolbutamide, glyburide, } \\
\text { nateglinide; losartan, candesartan, irbesartan; celecoxib, diclofenac, ibuprofen, } \\
\text { flurbiprofen, suprofen, naproxen, meloxicam, tenoxicam, piroxicam, lornoxicam; } \\
\text { phenytoin; fluvastatin; torsemide. }\end{array}$ \\
\hline Thiopurine S-methyltransferase & TPMT & 6-Mercaptopurine, 6-thioguanine, azathioprine \\
\hline Dihydropyrimidine dehydrogenase & DPD & 5-Fluorouracil, capecitabine \\
\hline $\begin{array}{l}\text { Uridin diphospho-glucuronic acid } \\
\text { transferase type 1A1 }\end{array}$ & UGT1A1 & Bilirubin, irinotecan \\
\hline Vitamin $\mathrm{K}$ epoxide reductase & VKORC1 & Warfarin, acenocoumarol, phenprocoumon \\
\hline Coagulation factor $\mathrm{V}$ & FV & Heparin, oral contraceptives, estrogens, SERMs \\
\hline $\begin{array}{l}\text { Organic anion transporting } \\
\text { polypeptide } 1\end{array}$ & OATP1B1 & Almost all statins, methotrexate, repaglinide, rifampin, torsemide, \\
\hline Major histocompatibility locus & HLA-B & HLA-B*5703 predicting Abacavir hypersensitivity \\
\hline
\end{tabular}

African American soldiers suffered from haemolysis during treatment with the antimalarial drug primaquine and other drugs, whereas this problem was almost absent in White Americans [2]. Electrophilic reactive metabolites of many drugs can only poorly be detoxified in carriers of the xchromosomally inherited G6PDH deficiency [3]. Nowadays, more than 150 mutations causing G6PDH deficiency are known. Because of this complex genetic background, analysis of the phenotype (enzyme activity in red blood cells) is still the preferred method of clinical diagnosis. Fortunately, the disease is mostly self-limiting. Nevertheless, the drugs causing haemolysis should be avoided in known carriers of the G6PDH deficiency.

A second lesson from the G6PDH issue is about interethnic differences in the risk-benefit ratio of drugs. Haemolysis after primaquine was very rare in northern European Caucasian populations, but it is a problem in $10 \%$ or even much more of African and some Mediterranean populations. These inter-ethnic differences in the population frequencies of genetic polymorphisms are extremely important in terms of the worldwide distribution of drugs. Each company interested in worldwide marketing of a drug is well advised to carefully study the pharmacogenetics concerning inter-ethnic differences in the genes relevant for drug disposition and pharmacodynamics [4]. And, of course, these inter-ethnic differences have also to be considered in pharmacovigilance, and adverse drug reporting (ADR) reporting should always ask for ethnicity. Differences in frequencies of pharmacogenetic polymorphisms are a most important cause behind interethnic differences in response to drugs [5].

The G6PDH story tells a third very important point important particularly for the legal, social and ethical implications of pharmacogenetic diagnostics - namely, that many pharmacogenetic variants have some good and some bad sides for human health: carriers of the G6PDH deficiency are at risk for drug-induced haemolysis. However, they are protected from malaria to some extent, and it is well known that the worldwide map of high prevalence of G6PDH deficiency largely overlaps with malaria prevalence.

\section{Butyrylcholine esterase}

The muscle relaxants succinylcholine and mivacurium act significantly longer in about $0.1 \%$ of patients compared with the other $99.9 \%$, and if physicians do not make 
appropriate provisions for these $0.1 \%$ of patients, this may even cause fatalities due to apnoea. This prolonged action of succinylcholine and mivacurium is due to an inherited lack of plasma cholinesterase, also known as butyrylcholine esterase (BCHE) [6]. Although we could genotype patients (i.e. analyse by molecular genetic methods) for the underlying variants, measurement of the phenotype (the BCHE activity) is still preferred because it is easy to perform and is also informative on acquired liver disease.

\section{$N$-acetyltransferase type 2}

Acetylation is a phase II drug metabolism reaction in several xenobiotics, including the anti-tuberculosis drug isoniazid. About half of Caucasian populations are rapid acetylators, whereas the other half are slow acetylators of isoniazid [7, 8]. The responsible enzyme was identified as arylamine $\mathrm{N}$ acetyltransferase and later specified as the type 2 enzyme (NAT2) [9]. There are several amino acid substitutions in that enzyme, resulting in low protein stability or low enzyme activity [10]. With the same dose of the drug isoniazid, the $50 \%$ slow acetylators have high blood concentrations and, most likely, a better antibacterial efficacy, but they may have more adverse effects. The other $50 \%$, the rapid acetylators, have low parent active drug concentrations in their blood and tissues. Compared with the slow acetylators, the drug is less effective in this latter group, and this group probably has less adverse effects.

The acetylation polymorphism has been known for more than 50 years, and many physicians are aware of it. However, the NAT2 polymorphism is still not usually considered in isoniazide prescriptions. This appears to be a general feature of pharmacogenetic research findings: knowing about an apparently medically significant genetic polymorphism does not necessarily mean that physicians start to use that knowledge to the benefit of the patient. The latest clinical trial on whether or not isoniazide dose adjustment according to NAT2 genotype really reduces isoniazide hepatotoxicity and improves therapeutic efficacy has not yet been completed [11], even 50 years after discovery of the NAT2 polymorphism.

\section{Cytochrome P450 2D6}

A complete lack of cytochrome P450 2D6 (CYP2D6) enzyme activity was first identified in 1975 and was based on the appearance of exaggerated adverse effects in patients receiving the drugs debrisoquine and sparteine [12, 13]. Following identification of the gene [14, 15], numerous variants resulting in deficient activity, low activity and ultra-rapid activity were identified [16-18] and, at least in Caucasian populations, the CYP2D6 poor metabolizer phenotype could be reasonably well predicted from the genotype [19]. There is a wide range of enzyme activities ranging from a complete lack of enzyme activity in the socalled poor metabolizers (PM), to very low activity in carriers of one deficient and one low-activity allele, to intermediate activity in heterozygous carriers of one active and one deficient allele, to high activity in the extensive metabolizers (EM) and up to extremely high activity in the ultra-rapid metabolizers (UM).

The clinical impact of the CYP2D6 genotype depends on whether the drugs are bioactivated by CYP2D6 or inactivated. Some of the substrates of CYP2D6 are summarized in Table 1 [20]. Most of these are metabolized to inactive metabolites. However, there are notable exceptions of drugs bio-activated by CYP2D6, such as codeine, tramadol, tamoxifen and encainide. It is difficult to understand why the extensive variation of CYP2D6 is not yet regularly considered in medicine. Dose-dependent adverse drug effects and thus the quality of life, but also survival of breast cancer patients receiving tamoxifen may depend on this enzyme [21]. In order to promote further concrete application of and research on CYP2D6 pharmacogenetic genotyping in medical practice, dose-adjustment recommendations based on available published pharmacokinetic data have been derived (see [22-24]). These CYP2D6 genotype-based dosage recommendations illustrate how individualized medicine may work in daily medical practice.

\section{Cytochrome P450 C19}

A complete lack of the enzyme CYP2C19 was first described to result in the slow elimination of the $\mathrm{S}$ enantiomer of the antiepileptic drug mephenytoin [25]. CYP2C19 metabolizes all currently marketed proton pump inhibitors, several antidepressants and the antimycotic drug voriconazole. There is absolutely no activity of this enzyme in about $3 \%$ or Caucasians and in about $20 \%$ of Asian populations. This is due to a few variants; in Caucasians, most inter-individual variation in function is explained by the variant $C Y P 2 C 19 * 2$ [26], but worldwide a number of other variants may have to be considered, in particular CYP2C19*3 [27, 28]. A co-dominant mode of inheritance has been consistently seen, and thus heterozygous carriers of CYP2C19 have about half of the activity of the homozygous carriers. A promoter variant has been described recently, termed $C Y P 2 C 19^{*} 17$, resulting in very rapid metabolism [29]. The medical impact of CYP2C19 depends on whether the drugs are converted to active or inactive metabolites. Tricyclic antidepressants are converted by CYP2C19 to similarly active metabolites. The prodrug clopidogrel, a most important antithrombotic agent, is bioactivated partially via CYP2C19 [30]. It has not yet been unequivocally determined to what extend routine 
prospective CYP2C19 genotyping in treatment with clopidogrel might reduce trombosis on the side or bleeding on the other side. However, the proton pump inhibitors are deactivated, and a significant improvement of therapy with proton pump inhibitors may be obtained by genotyping for CYP2C19 [31].

\section{Cytochrome P450 2C9}

A genetically determined low activity of CYP2C9 is long known from tolbutamide and phenytoin metabolism. In Caucasians, this aberration is mostly due to two frequent amino acid substitutions in the enzyme, termed CYP2C $9 * 2$ and $C Y P 2 C{ }^{*} 3[32,33]$. Worldwide, a number of other variants have also to be considered $[34,35]$. The CYP2C9 polymorphisms are relevant for the efficacy and adverse effects of numerous nonsteroidal anti-inflammatory agents [36-39], sulfonylurea antidiabetic drugs (see [40-43]) and, most critically, oral anticoagulants belonging to the class of vitamin $\mathrm{K}$ epoxide reductase (VKORC1) inhibitors [44]. Numerous studies have shown that the CYP2C9 polymorphism should be considered in warfarin therapy, and practical algorithms how to consider it in therapy are available [45].

\section{Thiopurine S-methyltransferase}

The autosomal co-dominant genetic polymorphism in thiopurine S-methyltransferase was detected about 30 years ago and is a major determinant of the efficacy and toxicity of 6-mercaptopurine, 6-thioguanine and azathioprine [46]. Amino acid substitutions Ala18Pro, Ala154Thr and the combination of Ala154Thr with Tyr240Cys, known as TPMT alleles $* 2, * 3 \mathrm{C}$ and $* 3 \mathrm{~A}$, respectively, have allele frequencies of $0.4,0.2$ and $4.4 \%$ in Caucasian populations, respectively, and explain most of the low thiopurine Smethyltransferase activity phenotypes. The frequency of the carrier of two inactive TPMT alleles is low $-0.3 \%$ in Caucasians populations. Nevertheless, due to the potentially fatal consequences of ignoring TPMP deficiency [47], the identification of such individuals and of the about $10 \%$ of heterozygous carriers is recommended, even in the drug label [48]. Although recommended, still less than $12 \%$ of the oncology, haematology and paediatrics department in the EU regularly performed TPMT genotyping or phenotyping before administrating thiopurine drugs, and 53\% did not perform the test at all in 2005 [49].

\section{Dihydropyrimidine dehydrogenase}

The enzyme dihydropyrimidine dehydrogenase (DPD) is rate limiting in terms of the catabolism of uracil and thymine and converts 5-fluorouracil (5-FU) to the inactive dihydrofluorouracil. In humans, more than $80 \%$ of admin- istered 5-FU is degraded via DPD. Independently from 5FU therapy, a deficiency of DPD may be associated with severe neurological deficits, but there is no simple genotype-phenotype relationship [50]. Deficient or very low DPD activity may result in severe adverse effects from 5-FU [51] or capecitabine. In some clinics, patients are routinely tested for one relatively frequent IVS14+1G $>$ A splice-site polymorphism [52]. However, there are a number of other rare genetic variants in DPD, and only a small fraction of patients with severe 5-FU toxicity have that IVS14+1G $>$ A splice-site variant. We are not aware of a study clarifying whether 5-FU dose reduction or choosing alternative drugs would be the better choice.

\section{Uridin diphospho-glucuronic acid transferase type 1 A1}

UGT1A1 is the bilirubin glucuronidase, and benign hyperbiliribinema, known as Gilbert-Meulengracht disease, is mostly explained by a promoter variant with lower transcriptional activity of $(\mathrm{TA})_{7}$ carriers compared with (TA) 6 carriers [53]. UGT1A1 also contributes to the glucuronidation of drugs and, in particular, to the glucuronidation of the topoisomerase inhibitor irinotecan. Consideration of the UGT1A1 genotype is recommended in the irinotecan drug label [48]. The UGTIA1 genotype appears to predict an increased risk of severe (grade 3 and grade 4) haematotoxicity in irinotecan high-dose schemes [54]. The full impact of this $U G T 1 A 1$ polymorphism is apparently not yet known. In addition, as several other drug also have a potential to contribute to glucuronidation, there may be socalled metabolic crosstalk, i.e. the low bilirubin glucuronidation capacity may result in competitive inhibition of the thus higher unconjugated bilirubin with several drugs at the efflux transporters.

\section{Genetic variation in drug transport}

Only in the past 15 years have pharmacologists became fully aware of the impact of transmembrane drug transporters on the uptake of drugs from the gut into the human body and from the circulation into the target tissues and into the metabolizing and eliminating organs. This carriermediated transmembrane transport becomes particularly important in molecules with larger molecular diameters [55]. To understand the pharmacokinetics of drugs, even in a single cell, phase 0 (influx transport), phase 1 (mostly oxidative or reductive biotransformation), phase 2 (conjugations) and phase 3 (efflux transport) have to be considered. There are only a few drugs for which all of the transporter proteins relevant from uptake to final elimination of the metabolites from the body are fully identified. When the entire multi-organ organism is considered, the situation is even more complex. The transporters 
act as the most important determinants of barriers between body compartments, such as the blood brain barrier. Elucidation of these minimally four phases $(0,1,2$, and 3 ) of pharmacokinetics of a drug in experimental or clinical studies may be a first step towards a complete system biological understanding of the pharmacogenetics of a drug.

One of the human multiple drug resistance (MDR) conferring transporters, MDR1, was among the first transporters extensively screened for genetic polymorphisms. A number of variants having some functional impact have been identified [56]. However, subsequent studies often resulted in discrepant results $[57,58]$ so that polymorphisms in MDR1 cannot yet be considered as valid biomarkers, because it is not clear how exactly these polymorphisms should be considered in drug therapy or drug development. There are numerous non-synonymous (i.e. protein sequence changing) polymorphisms in MDR1 and in other efflux transporters, such as breast cancer resistance protein (BRCP) and in the multidrug resistanceassociated proteins (MRPs) (Table 2).

The drug transporter organic anion-transporting polypeptide OATP1B1 (synonym OATP-C) is primarily expressed in hepatocytes and catalyses the influx-transport of many organic anions (Table 2). A number of polymorphisms have been found [59], and two variants have frequently been analysed clinically: the highly active Asn130Asp variant and the low-active Val174Ala variant [60]. Since OATP1B1 typically catalyses the influx transport of organic anions and CYP2C9 typically metabolizes such organic anions, epistatic effects between OATP1B1 and CYP2C9 may become an important focus of molecular and clinical pharmacological research [61] (Table 2). Renal tubular secretion of organic anions is mediated by organic anion transporters OAT1, OAT3 and OAT4, but polymorphisms in these transporters can explain only a relatively small fraction of the interindividual pharmacokinetic variation of the presumed substrates of these transporters [62].

Many drugs belonging to the organic cations can be transported into the cells by the organic anion transporters OCT1, OCT2 and OCT3. These three transporters differ particularly in their tissue distribution. OCT1 may be relevant for hepatic uptake of the cationic metformin into the hepatocyte. While little variation in metformin plasma pharmacokinetics was explained by polymorphisms in OCT1, polymorphisms in that gene appeared to modulate appeared to modulate the access of metformin to its target sites in the liver cell [63]. Although these data are preliminary because of the small sample size, the results illustrate an important point concerning drug transporter pharmacogenetics: while the plasma compartment is a convenient one for pharmacokinetic analyses, it is often not the right compartment to study clinically relevant effects of drug transporter polymorphisms. To understand the medical impact of polymorphisms in drug transporter genes, drug concentrations have to be analysed in the effect compartments. Alternatively, one may look for and use valid surrogate tissues or surrogate cells of the true effects compartments.

Genetic variation in drug targets

\section{Vitamin $K$ epoxide reductase}

Only recently has the gene coding for vitamin $\mathrm{K}$ epoxide reductase (VKORC1) been identified [64]. A certain haplotype in VKORC corresponds to low expression and high sensitivity to the oral anticoagulants warfarin, acenocoumarol and phenprocoumon (dicumarol) [65]. CYP2C9 plus VKORC genotyping may soon become a clinical routine in patients going to receive oral anticoagulants such as warfarin or acenocoumarol.

\section{Factor $V$}

Coagulation factor $\mathrm{V}$ is a cofactor of the prothrombinactivating complex, and the arginine ${ }_{560}$-to-glutamine substitution in factor $\mathrm{V}$, known as the Leiden variant [66], results in higher protein stability and thus in higher coagulation compared with the arginine 560 wild type. In drug therapies increasing the risk of thrombosis, the factor $\mathrm{V}$ polymorphism is an important modulator of that risk.

Table 2 Potential impact of polymorphisms in drug transporters and drug-metabolizing enzymes depending on the chemical nature of the drug

\begin{tabular}{lll}
\hline Molecular characteristics & Examples of typical transporters (genes) & Typical enzymes \\
\hline $\begin{array}{l}\text { Large amphipathic, mostly } \\
\text { apolar }\end{array}$ & $\begin{array}{c}\text { MDR1 (ABCB1), BCRP (ABCG2), MRP1 (ABCC1), } \\
\text { MRP2 (ABCC2) } \\
\text { Organic anionic }\end{array}$ & CYP3A4, CYP3A5 \\
& OATP1A2, OATP1B1, OATP2B1, OAT1, OAT2, & CYP2C9 \\
$\begin{array}{l}\text { Organic cationic } \\
\text { Omino acid and peptide } \\
\text { OCrivatives }\end{array}$ & LAT1, LAT2, TAT1, PepT1, PepT2 & CYP2D6 \\
$\begin{array}{l}\text { Nucleoside analogues } \\
\text { hCNT1, hCNT2, hCNT3, hENT1, hENT2, hENT3 }\end{array}$ & $\begin{array}{c}\text { Numerous enzymes of amino acid metabolism } \\
\text { nucleotide metabolism }\end{array}$ \\
\hline
\end{tabular}


Particularly among smokers, the prothrombotic risk of oral contraceptives is significantly increased in carriers of the factor V Leiden variant. Molecular genetic analysis for that variant has become a routine part of the clinical differential diagnosis of venous thrombosis. Routine genotyping before clinical medication with oral contraceptives, oestrogens or selective oestrogen receptor modifiers. such as tamoxifen or other drugs increasing risk of thrombosis, is currently not recommended on a routine basis [67]. However, this recommendation not to perform routine factor $\mathrm{V}$ pharmacogenetic testing at present depends on several social, medical and economic circumstances and, consequently, the recommendation not routinely to genotype preemptively may change in the coming years.

Genotyping for the factor $\mathrm{V}$ polymorphism has been introduced into the routine practice of drug development: In phase II clinical drug trials (trials in which the benefits of the drug have not yet been proven) with drugs having a prothrombotic risk, all carriers of the factor V Leiden variant should excluded for safety reasons. This is an example of how pharmacogenetic genotyping may improve safety of volunteers in early clinical drug development.

\section{Beta adrenergic receptors $A D R B 1$ and $A D R B 2$}

There are genetic polymorphisms in the gene coding for the beta $_{1}$ adrenergic receptor (ADRB1) and in that coding for the beta $_{2}$ receptor (ADRB2). In ADRB1, a Ser49Gly variant may be associated with enhanced agonist-induced downregulation, whereas a Gly389Arg variant was found to bring about a fourfold higher agonist stimulated signal transduction to the $\mathrm{G}_{\mathrm{s}}$ protein $[68,69]$ compared with the Gly allele. Recent data have shown that the effects of the ADRB1 polymorphism may differ depending on the specific beta- blocker used [70]. There is extensive clinical data on these two ADRB1 polymorphisms and hypertension, response to beta-blocker treatment, susceptibility to heart failure and response to treatment. However, few data are consistent between all studies [71] and, therefore, according to the understanding of the authors, the ADRB1 data are not yet clear enough to be considered as a valid biomarker (Table 1) in routine drug therapy and drug development.

Also in the Beta $_{2}$ receptor gene, ADRB2, there are two frequent variants resulting in Arg16Gly and Glu27Gln amino acid substitutions. Despite early promising results showing that these variants may modify the risk for bronchogenic asthma, other diseases or the response to therapy, data from many subsequent studies have been inconsistent [72].

Polymorphisms in many drug receptors have been studied in the past 15 years, and the different groups have frequently come to divergent conclusions. However, not all presumed discrepancies are real discrepancies. There are different levels of pharmacogenetic and genomic research (Table 3), starting with molecular research (level 1), then going into different levels of translational research and finally ending with clinical therapeutic (level 4) or clinical diagnostic (level 6) research. A genetic variant with a proven functional impact at low-complexity level 1 may not have any clinical impact at all, or only have clinical impact under certain conditions to be identified. On the other hand, we will not be satisfied with mere association research on a variant apparently having a clinical impact as long as the molecular effects are obscure. While in therapeutic research clinical endpoints (level 4) are indispensable in deciding upon the value of a given therapy, in pharmacogenetic and genomic research often less complex systems (levels 2 and 3) may be preferable, at least at the beginnings of research.

Table 3 Levels of research in pharmacogenetics and genomics: From well defined molecules to complex biological and social interactions

\begin{tabular}{|c|c|c|c|}
\hline Level & Focus on & $\begin{array}{l}\text { Complexity of the } \\
\text { studied system }\end{array}$ & Some possible confounders to be considered \\
\hline 1. & Single molecule molecular & Low, well defined & \\
\hline 2. & Cell biology & Moderate & $\begin{array}{l}\text { Cell type, cell passage number, culture medium, substrate and } \\
\text { substrate concentrations }\end{array}$ \\
\hline 3. & Human clinical endophenotypes & High & $\begin{array}{l}\text { Dose, ethnicity, duration of exposure, age, gender, co- } \\
\text { medication }\end{array}$ \\
\hline 4. & $\begin{array}{l}\text { Response of humans to drugs (efficacy } \\
\text { and adverse events) }\end{array}$ & Very high & $\begin{array}{l}\text { Dose, ethnicity, type of disease, age, gender, other inclusion } \\
\text { and exclusion criteria }\end{array}$ \\
\hline 5. & Human disease susceptibility & Extremely high & Types and duration of exposure to environmental factors \\
\hline 6. & $\begin{array}{l}\text { Research on value of clinical } \\
\text { pharmacogenetic diagnostics }\end{array}$ & & \\
\hline 7. & $\begin{array}{l}\text { Economic and ethical aspects of } \\
\text { pharmacogenetics }\end{array}$ & & $\begin{array}{l}\text { Dependent on the respective health insurance system and drug } \\
\text { and health service costs }\end{array}$ \\
\hline
\end{tabular}


Immunological mechanisms and adverse drug events

While most of the polymorphisms introduced above may be associated with type A (aggravated, overdose-like) adverse drug reactions, type B (bizarre, idiosyncratic, mostly allergic) adverse drug reactions may be explained by polymorphisms in genes of the major histocompatibility complex. Severe (and in some cases fatal) allergic reactions to the HIV nucleoside analogue drug abacavir have been explained by the HLA-B*5701 allele, and a HLA-B*5701, HLA-DR7, and HLA-DQ3 haplotype even had positive and negative predictive values of 100 and $97 \%$, respectively [73], strongly advocating routine testing before abacavir prescription. Such a testing may not only be medically needed, but it may also be cost-effective [74].

The concept of individualized drug therapy

\section{Pharmacogenetics of drug target concentrations}

Individualized drug therapy means that the choice of the drug and the choice of drug dosing regimens are selected based on the patient's individual requirements. In addition, the requirement for extra monitoring or for add-on therapies may depend on individual characteristics of the patient, including pharmacogenetic data. Optimal drugs and drug doses depend on age, gender, body weight, co-morbidity, organ functions, drug-drug interactions, lifestyle, culture, ethnicity and pharmacogenetic data. All of these data and particularly their combinations may be so variable that in theory there should rarely be two patients for whom exactly the same medications may be optimal.

In the past 50 years clinical pharmacogenetics has mostly evolved as the pharmacogenetics of blood concentrations, with the assumption that blood concentrations mirror the concentrations at the target sites. In several therapeutic areas this concept has proved to be therapeutically valuable; for example, the monitoring of blood concentrations of aminoglycosides or immunosuppressive drugs has resulted in the therapy with these drugs becoming significantly more safe and efficient. More than $50 \%$ of all adverse drug reactions are dose-related type A reactions, so that an understanding of the causes behind individually wrong blood concentrations of drugs may significantly reduce adverse drug reactions. However, target concentrations in many instances are not the plasma concentrations but concentrations in specific tissues at specific target organs. One example is the recent study on OCT1 variants and metformin pharmacokinetics and dynamics [63]. Apparently the effect of functional OCT1 variants was not seen in the blood concentrations [63], but the transporter variants had some impact on effects, indicating that they had an effect on the transfer of the drug to its target compartment, the liver.

\section{Drug effects and therapy recommendations}

To the best of our knowledge, in 2007, phenotyping or genotyping for pharmacogenetic polymorphisms had a firm regular place in only a few hospitals or doctor's offices. However, in a larger number of institutions, genotyping is sometimes performed in some patients with adverse drug events or in patients refractory to therapy $[75,76]$. As with any laboratory test, pharmacogenetic genotyping does not make much sense unless clear rules are available so that practical conclusions can be drawn from the results of the genotyping tests. Based on the bioequivalence concept to achieve similar blood concentrations in all patients, it is possible to calculate preliminary doses that take genotypedependent differences in bioavailability and drug clearance into consideration [77]. These recommendations follow bioequivalence concepts generally accepted by regulatory authorities - that is if two brands of a drug result in blood concentrations which do not significantly differ, the two brands can be considered to be equivalent. Similarly, it is possible to find equivalent doses for different pharmacokinetic genotypes. Figure 1 illustrates up to how much such doses may have to be adjusted to achieve equivalent drug concentrations.

Of course, in prodrugs bioactivated via a polymorphic enzyme, such as codeine, tramadol, tamoxifen, encainide, clopidogrel and others, the relationship reverses: in these drugs, deficient or very slow metabolizers might better receive alternative drugs, intermediate metabolizers might receive slightly higher than average doses and ultra-rapid metabolizers should receive lower than average doses instead of higher than average doses [78].

Such a concept of pre-emptive pharmacogenetic diagnostics and dose adjustments as illustrated in Fig. 1 needs evidence-based verification by controlled diagnostics trials. There are some controlled trials showing that proton pump inhibitors should be dosed according to CYP2C19 genotype [31]. Data supporting the concept of preemptive NAT2 genotyping in therapy with isoniazid date back 50 years [7]. Nevertheless, we still need trials on NAT2 genotyping in the treatment with isoniazid [11] since theoretical considerations and some early clinical data suggest both pros and cons from rapid and slow acetylation in terms of the problem of hepatotoxicity. There are initial data confirming that prospective genotyping for CYP2C9 may make therapy with warfarin safer than current therapy as usual [80]. At a first glance it is surprising that pharmacogenetics can improve therapy with oral anticoagulants. There is a good monitoring for oral anticoagulants. However, if physicians are aware in advance who is at a particular risk of overanticoagulation, they can select individual loading doses. More trials in this area are ongoing to test the concept that prospective genotyping of CYP2C9 and VKORC1 in 


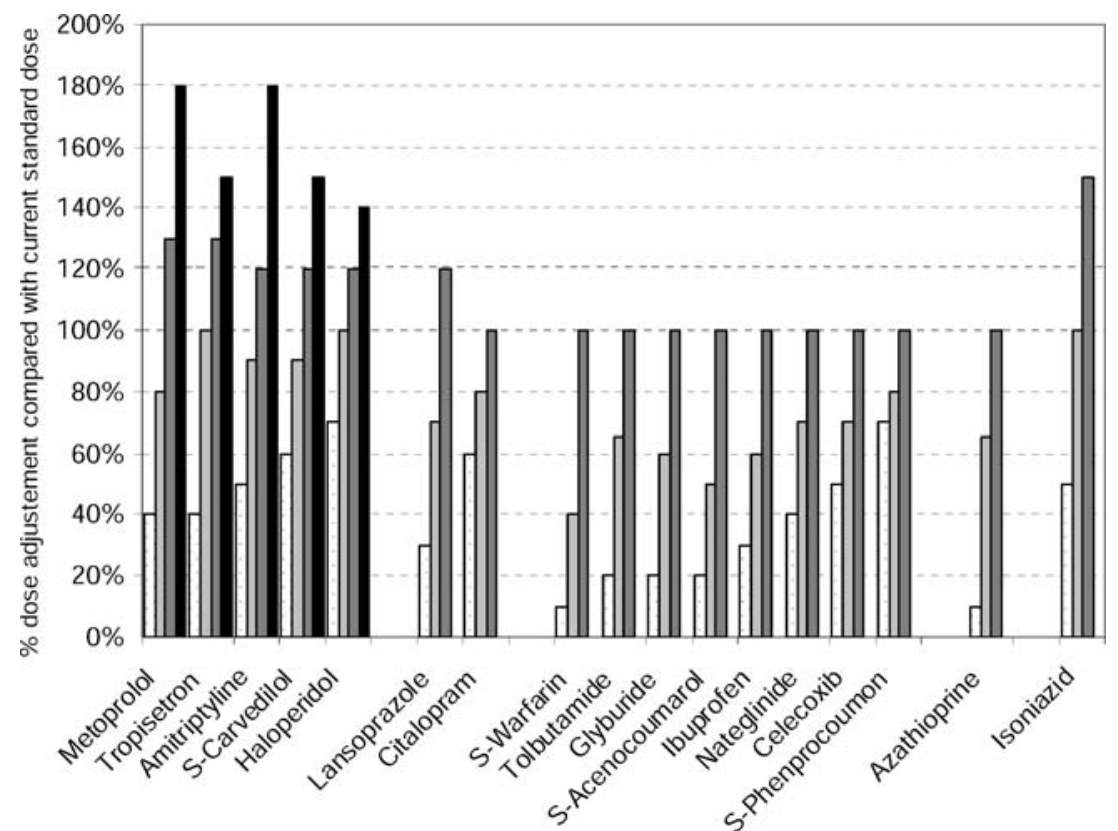

Fig. 1 Preemptive genotype-based dose adjustment. A $100 \%$ of the dose would correspond to the currently recommended dose according to the drug information to prescribers. Based on pharmacokinetic data analyses ,one might recommend for some patients lower or higher doses compared to the standard doses (see [77, 79] for more details)

initiating conditions were not known. In parallel, the functional nature of the genes considered in pharmacogenetic research broadened from drug-metabolizing enzymes to almost all other classes, such as drug transport, DNA-repair, cell-cycle regulation and signal transduction [4]. The overall number of publications studying pharmacogenetic polymorphisms in relation to disease risk exceeds several-fold those studying the polymorphisms in relation to response to drugs, and it is not possible to give in this review a meaningful summary of that research on the hundreds of candidate genes as disease susceptibility factors. Still, it might be interesting to analyse this research systematically in order to improve future strategies in pharmaocogenetic and genomic research. Also, almost all recent genome-wide screens did not focus on the response to drugs but on the identification of genotypes predisposing to certain multifactorial and polygenic diseases.

\section{Chemical toxicology and carcinogenesis}

Reactions in foreign compound metabolism may result in biologically or chemically active compounds or in inactive compounds and, therefore, the individual human set of toxifying and detoxifying genes may determine our risk for disease. Enzymes such as the acteyltransferases, glutathione S-transferases M1 and T1, paraoxonases, myeloperoxidase have protein coding variants resulting in a broad range of activities between a complete lack of activity and extremely high activity depending on the enzyme and the individual genotype. Therefore it is evident that such genetic variants 
may play a role in chemical carcinogenesis, in chemically induced neurodegenerative disease or in chemically induced endothelial damage and arteriosclerosis. The following two examples, CYP2D6 and GSTM1, may serve to illustrate some of the general points and problems, which are also illustrated in Fig. 2.

Soon after the discovery of the CYP2D6 polymorphism, scientists started investigating polymorphisms as a risk factor for lung cancer. The motivation to do this research can be understood: there are big interindividual differences in susceptibility to lung cancer, and scientists at those times knew that all cytochrome P450 enzymes can bioactivate procarcinogenes. Indeed, the results of one of these studies indicated that rapid metabolizers have a significantly increased risk [84]. A number of other studies could not confirm this data absolutely [85], and some could, but only in subgroups. However, at the present time, there are doubts that CYP2D6 plays a significant role in lung cancer. There are some thoughts on carcinogens that might be bioactivated by CYP2D6, but there is no proof that these are the crucial ones in lung cancer. Nowadays one would like to see large confirmatory studies proving the impact of CYP2D6 in lung cancer.

Glutathione S-transferase M1 is a phase II enzyme involved in the detoxification of several polycyclic aromatic hydrocarbons. About $50 \%$ of the Caucasian population have a complete lack of the enzyme due to a large genomic deletion [86]. This provided the basis for studying this enzyme in relation to lung cancer risk, and some studies indeed described an increased risk in individuals lacking this enzyme, but no such effects could be found in a sufficiently powerful meta-analysis [87]. In addition, initial genomewide analyses on lung cancer risk factors have not identified this lack of a detoxifying enzyme as a risk factor [88].

\section{Mastering a mass of genomic variation}

The vast extent of inherited variation in the human genome only recently became apparent after almost the complete DNA sequences of the human genome became available. One can extrapolate [89] that very soon several human individuals will be entirely sequenced and that this will provide a more clearly understanding of inter-individual variation in human genomes. At the present time about 12 million single nucleotide polymorphisms (SNPs) have been identified in the human genome [90-92]. In addition, there are probably more than 100,000 insertions and deletions. There is also a large class of genetic variations summarized as variable number of tandem repeat polymorphisms (VNTR) (Table 4). These include variable numbers of dinucleotide repeats, such as a variable number of TA in the TATA box in the core promoter of bilirubin glucuronyltransferase UGT1A1 and larger repeat units, such as the 16 amino acid (48 bp) repeat in the dopamine D4 receptor [93]. Only recently we have learned that there are at least 1500 large genomic segments occurring interindividually in variable copy numbers [90-92]. The total amount of

\section{Research on disease susceptibility}

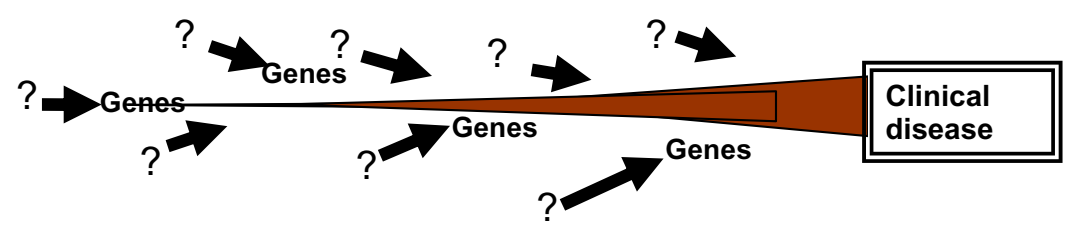

Usually: Multiple mostly unknown interacting environmental and genetic factors

Research on drug therapy response

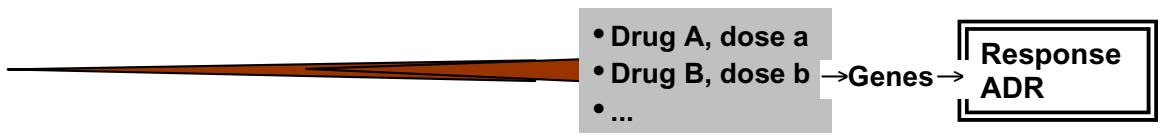

Usually: Well-documented therapies with chemically defined drugs and well-documented doses

Fig. 2 Differences between pharmacogenomic studies on disease susceptibility (upper part) and drug response (lower part). In the pathogenesis of diseases, mostly multiple endogenous factors (indicated by the question marks, because these exogenous factors are mostly not well documented) interact at multiple time points with one gene or multiple genes. On the other hand, in drug therapy studies, the exposure (i.e. type and dose of drug, optimally even plasma concentrations of the drug to differentiate between pharmacokinetic and pharmacodynamics sources of variation) of the drugs are known. In theory, this should make the identification of genes modulating response to the drugs easier than the identification of genes responsible for the development of diseases. $A D R$ Adverse drug reaction 
Table 4 Types and amount of interindividual variation in the human genome

\begin{tabular}{|c|c|c|c|}
\hline $\begin{array}{l}\text { Genetic change/ } \\
\text { variation }\end{array}$ & Abbreviation & Description & $\begin{array}{l}\text { Frequency in human } \\
\text { genome }\end{array}$ \\
\hline $\begin{array}{l}\text { Single nucleotide } \\
\text { polymorphism }\end{array}$ & SNP & $\begin{array}{l}\text { Typically two different nucleotides (biallelic SNPs) at one defined position, but } \\
\text { more rarely also triallelic variants occur }\end{array}$ & $12,000,000$ \\
\hline $\begin{array}{l}\text { Deletions/ } \\
\text { Insertions }\end{array}$ & InDel & $\begin{array}{l}\text { Deletions (or insertions, depending on the allele frequencies) of between } 1 \text { to } \\
1000 \text { nucleotides. More frequent are deletions of one or three basepairs. }\end{array}$ & $>1,000,000^{\mathrm{a}}$ \\
\hline $\begin{array}{l}\text { Varying number of } \\
\text { tandem repeats }\end{array}$ & VNTR & $\begin{array}{l}\text { Microsatellites, also termed short tandem repeat (STR) polymorphisms are } \\
\text { typically tandem repeats of two, three or four nucleotides, but repeats up to } \\
\text { ten nucleotides in length may also classified in this group } \\
\text { Minisatellites are VNTR polymorphisms in which } 10-100 \text { nucleotides are } \\
\text { repeated in variable numbers. Repeated segments often do not have exactly } \\
\text { identical sequences. } \\
\text { VNTRs with larger repeat units }(100-1000 \mathrm{bp}) \text { are termed satellites. }\end{array}$ & $>500,000^{\mathrm{a}}$ \\
\hline $\begin{array}{l}\text { Copy number } \\
\text { variation }\end{array}$ & $\mathrm{CNV}$ & $\begin{array}{l}\text { Inheritable deletion or multiplication of DNA segments larger than } 1 \mathrm{~kb} \text {. } \\
\text { Currently, about } 1500 \mathrm{CNV} \text { s distributed through all chromosomes are known; } \\
\text { estimated to cover } 12 \% \text { of the human genome length. }\end{array}$ & $\begin{array}{l}>1500 \text { loci covering } \\
12 \% \text { of the genome }\end{array}$ \\
\hline \multicolumn{4}{|c|}{ Epigenetic and somatic variations of the human genome } \\
\hline \multicolumn{2}{|c|}{$\begin{array}{l}\text { Cell karyotype and somatic } \\
\text { mutations }\end{array}$} & $\begin{array}{l}\text { Typically in tumours where DNA recombination and repair machineries are } \\
\text { damaged, but also in some inherited diseases. }\end{array}$ & \\
\hline DNA methylation & & $\begin{array}{l}\text { Methylation of the cytosine residues of } \mathrm{CpG} \text { repeats (known as } \mathrm{CpG} \text { islands) of } \\
\text { the DNA transmitted through generations. Methylation of } \mathrm{CpG} \text { islands } \\
\text { located in the promoter or the 5-untranslated region of the genes causing } \\
\text { down-regulation, whether methylation in the gene coding regions can cause } \\
\text { up-regulation of the gene expression. }\end{array}$ & $>20 \%$ of all genes \\
\hline
\end{tabular}

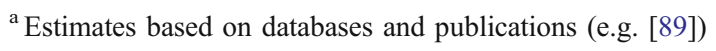

inherited epigenetic variation may even be larger, and at least $20 \%$ of all genes are differentially methylated in the promoter regions or in the coding regions [90-92].

A central question behind this mass of genomic and epigenomic variation is to identify what is biologically and medically relevant (Fig. 3). Polymorphisms affecting gene expression may reside anywhere - from directly in the core promoter, a few hundred or several ten thousands of bases upstream (in 5' direction) or even downstream in the intron and untranslated regions (UTRs) of the gene. Considering that the primary transcript is the entire region between the transcriptional start and the 3' end of the transcript, all polymorphisms in this segment may affect splicing. Interestingly, there is even more than one transcriptional start point for more than half of all genes, and such transcriptional start points may very depending on the tissues where the gene is expressed [94]. Polymorphisms in the coding region may be non-synonymous - i.e. resulting in amino acid substitutions - or they may be synonymous. The latter may still be functionally relevant by affecting mRNA stability or by affecting protein transcription because tRNAs for the different synonymous codons are not equally frequent in cells, and such different codon usage may not only result in differences in translational efficacy but, based on the example of an apparently functional polymorphisms in p-glycoprotein, it has been discussed that such polymorphisms may even result in differences in protein structure $[56,95]$.

\section{Copy number variation: CYP2A6, CYP2D6, GSTM1, GSTT1 and 1500 other such sites}

Deletions or duplications of large genomic fragments (ranging in size from $1 \mathrm{~kb}$ to more than $100 \mathrm{~kb}$ ) were thought to be specific for the unstable tumor genomes and more an exception in the genome of healthy non-malignant cells. This understanding had to be revised after a series of genome-wide analyses using SNP-microarrays and comparative genome hybridization analyses as well as in in silico comparisons of genomes from different individuals, which revealed more than 1400 deletions or duplications covering $12 \%$ of the "healthy" human genome sequence [92, 96-101]. This class of genetic polymorphisms, called copy number variations (CNV), represents stable genetic variation that undergoes Mendelian segregation as SNP, InDel or VNTR polymorphisms. Actually, such CNV 


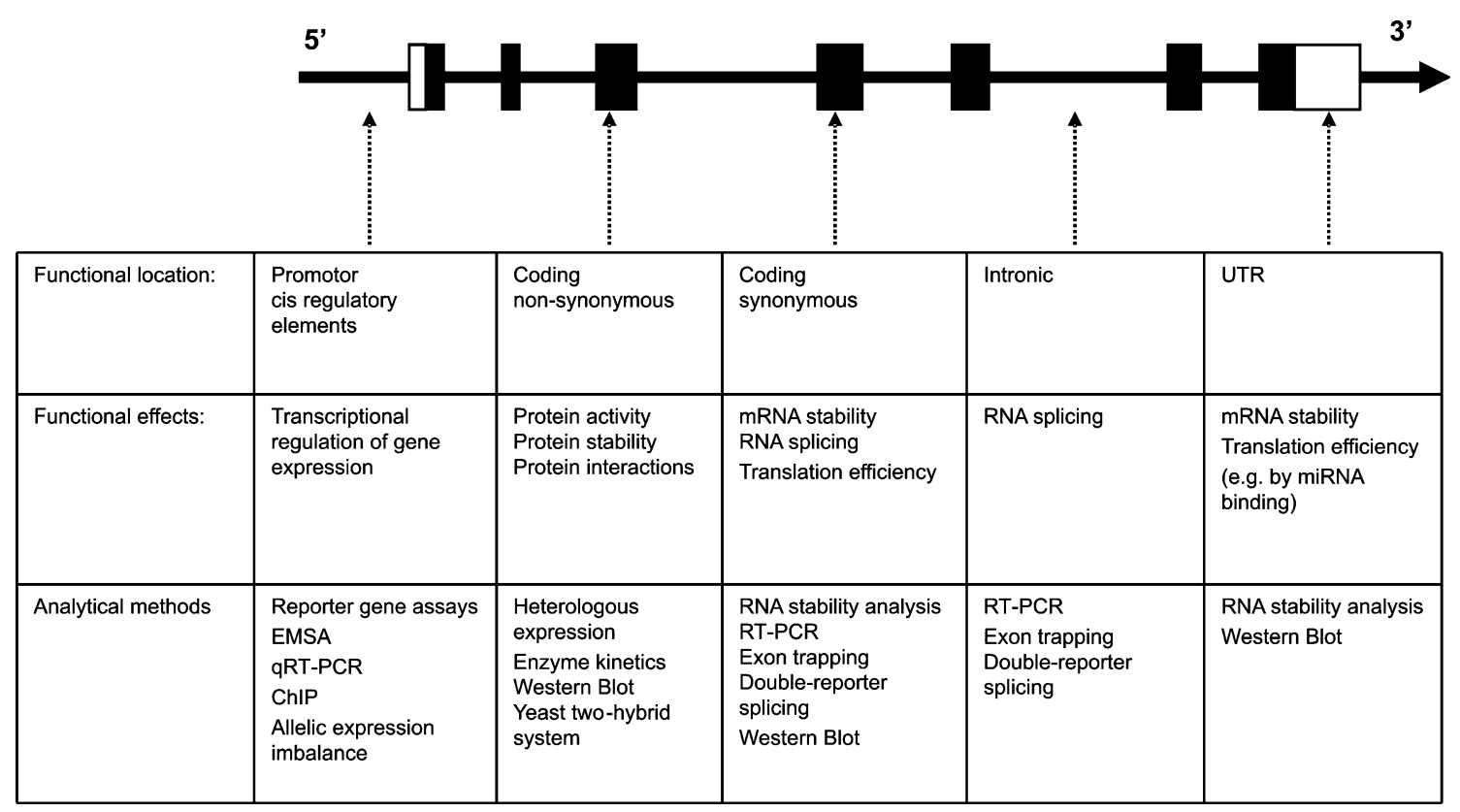

Fig. 3 Some of the possible functional effects of genetic polymorphisms [single nucleotide polymorphisms (SNPs), small insertions-deletions (InDels), varying number of tandem repeats (VNTRs)] depending on their localization in the genome. Upper part a hypothetical typical human gene is shown with the exons as black boxes and the 5' and 3'translated but not transcribed segments (untranslated regions, UTRs) as open boxes

ing procedures not using DNA from the tumours themselves. This was shown in leukemia cells where an additional chromosome containing the wild-type TPMT allele had significantly lower accumulation of thioguanine nucleotides or methotrexate polyglutamates, respectively [105]. Still, the TPMT genotype determined in the healthy non-malignant cells was associated with the response to mercaptopurine in the early course of childhood ALL [106].

\section{Genomics versus epigenomics}

We (scientists and physicians engaged in pharmacogenetics and genomics) have learned and repeatedly taught the following: analyzing inherited genetic variation has the big advantage that analysing the genome of one cell of an organism provides reliable information on all the other cells independent of age, tissue localization or environmental factors. However, there are somatic cell mutations as well as tissue-specific epigenetic effects, such as DNA methylation, histone modification or micro-RNA expression, that significantly and constantly can change the pattern of gene expression of the cell. Such changes can significantly modify drug efficacy or initiate adverse effects and, therefore, they have to be taken into account in future clinical pharmacology [107]. The simple lesson is that clinical pharmacology will have to learn about and do research in the fields of epigenomics and the worlds of small regulatory RNAs. Interesting first insights have appeared in relation to cancer chemotherapeutic drugs. 


\section{Epigenomics examples: DPD and MGMT}

The expression of the gene coding for dihydropyrimidine dehydrogenase (DPD) is a good marker for DPD deficiency and 5-FU toxicity. Apparently inherited genetic polymorphisms can explain only about one-third of the DPD enzyme deficiency and 5-FU toxicity [108, 109], but methylation of the DPYD promoter may account for a significant part of the as-yet unexplained low DPD activity both in tumour and healthy tissues, which is so important for adverse events from and the response to the drug [110 113]. Another example is the tumour-specific hypermethylation of MGMT. MGMT is a DNA-repair enzyme and its inactivation by changes in its methylation pattern can result in increased sensitivity of the tumour for alkylating drugs such as cyclophosphamide or carmustine [114].

\section{RNAi siRNA and miRNA}

The phenomenon of RNA interference (RNAi) regulating gene expression was first described in the nematode Caenorhabditis elegans [115]. In vertebrates and humans, small 19- to 22-nucleotide-long micro-RNA (miRNA) molecules are present in almost all cells; these are genetically encoded and regulate sequence-specific gene expression both by translational repression and mRNA degradation in normal development and cell regulation and in tumourigenesis [116, 117]. A SNP in the $3^{\prime}-$ UTR of the AGTR1 gene (rs5186) was found to affect the miRNA-155 recognition site and changes its silencing effects [118]. This result illustrates that genetic variations not only in the coding regions, promoters or intron-splicing sites of the genes but also in their 3'-UTRs could be of functional relevance mediated by miRNAs. Also, 14 of the human genome CNV regions harbor 21 of the known human miRNAs, which results in the deletion of entire miRNA genes [100]. There is, however, no data on phenotypic changes in the carrier of these CNVs.

Artificial 21- 22-bp-long double-stranded RNA molecules, called small interfering RNAs (siRNAs), are used to experimentally knock down gene expression [119]. RNAi is of general interest as a tool for analysing gene function. siRNAs have been shown to be able not only to specifically silence gene expression but also to do that in allele-specific manner even if the difference is a single base of a SNP [120-123]. This may allow genotype-specific therapy where a disease allele can be specifically targeted by siRNA if we can solve some practical problems [124].

\section{Molecular markers guiding drug therapy}

Therapy guided by molecular markers is becoming more and more of a medical routine. The status of breast cancer in terms of the expression of the HER2/neu and the oestrogen receptor determines therapy with agents specifically targeting the HER2 or the estrogen receptor (ER), namely trastuzumab (Herzeptin) and tamoxifen. The recommended tests for HER2 analysis are protein-based using immunohistochemical assays (IHC) or the direct detection of HER2 gene amplification using the fluorescence in situ hybridization (FISH) technique $[125,126]$. In the case of HER2, the qPCR assays are available both for the detection of HER2 amplification at the chromosome level and for HER2 transcripts in blood. These analyses show a gut correlation with the ICH and FISH methods but are still not established as a diagnostic tool [127-129].

Genomic analysis is not always the right method. To date, no quantitative method, such as real-time PCR, has been clinically implicated as being able to detect mRNA levels of ESR1 (the gene encoding for the ER $\alpha$ ) or HER2 or to detect gene amplification events for HER2 at the genomic DNA level. In the case of ER, the reason is that the protein stability but not the mRNA expression determines the levels of the ER in the tumour cells and thus the ER status of the tumors [130].

In addition to such targeted approaches, microarrays now reliably allow the simultaneous quantification of the mRNAs of 25,000 known human genes, but also of miRNA expression and even the identification of splice variants. These tools may serve for the differential diagnosis of diseases, for prognostic purposes and for the prediction of the response to drug therapy [131-133].

\section{The technical basis of pharmacogenetics and genomics}

Clinical pharmacology depends on reliable bioanalytical techniques and an understanding of their capabilities and limitations. In this review we restrict our discussion to mentioning the basic techniques of the wet and dry laboratories of pharmacogenetics and genomics (Tables 5 and 6).

Statistics, bioinformatics and systems biology

There are almost 12 million SNPs in the human genome [exactly 11,811,594 SNPs, of which 5,689,286 are validated SNPs, according to the last release of the database dbSNP, build 127 (accessed March 2007): http://www.ncbi. nlm.nih.gov/SNP/Notes/build127_announce.txt]. In the very near future, a clinical pharmacologist will have to deal not only with clinical and laboratory data on his/her volunteers or patients but also with data on the patient's 500,000 or 1 million SNPs. The cell biologist in the laboratory will also have data data on the same number of gene variants in the cell. And it is not only these 0.5 or 1 or 3 million SNPs, but many of these may interact - a phenomenon known in genetics as epistasis - to generate certain phenotypes. Consequently, an almost infinite num- 
Table 5 Important basic techniques for genotype analysis in pharmacogenetics and genomics

\begin{tabular}{|c|c|}
\hline Method & Short description and purpose \\
\hline Sanger dideoxy (end terminal) sequencing & Reading of DNA sequences, identification of new polymorphisms \\
\hline $\begin{array}{l}\text { Denaturing high performance liquid } \\
\text { chromatography (DHPLC) }\end{array}$ & $\begin{array}{l}\text { Variant and wild-type DNA forms differently shaped hybrid molecules (homoduplex versus } \\
\text { heteroduplex) which can be separated by ion-pair reverse phase HPLC to identify } \\
\text { polymorphisms. }\end{array}$ \\
\hline PCR-RFLP & $\begin{array}{l}\text { The polymorphic genomic region is amplified by PCR and cut by sequence-specific enzymes } \\
\text { (restriction endonucleases). The resulting fragments are analysed by electrophoresis and are } \\
\text { indicative of the genotypes. }\end{array}$ \\
\hline Pyrosequencing & $\begin{array}{l}\text { A method of DNA sequencing based on the sequencing by synthesis principle [134]. Used in SNP } \\
\text { genotyping and DNA methylation analyses. The principle behind this method is also the basis of } \\
\text { the current large-scale DNA sequencing known as } 454 \text { "next generation" [135] capable of } \\
\text { sequencing more than } 100 \text { million basepairs per day. }\end{array}$ \\
\hline $\begin{array}{l}\text { Single-base (primer) extension (also known } \\
\text { as mini-sequencing) }\end{array}$ & $\begin{array}{l}\text { Short oligonucleotides are annealed so that their } 3 \text { '-end directly upstream the polymorphic site. } \\
\text { Elongation of only one single base is performed by using a mixture of (fluorescently labeled) } \\
\text { ddNTPs without dNTPs. The products can be detected either with sequencing or using MALDI- } \\
\text { TOF detection system. Used as multiplex reaction in the SNPs genotyping }\end{array}$ \\
\hline DNA microarrays & $\begin{array}{l}\text { Microarray solid-phase bound DNA molecules to simultaneously genotype large numbers of SNPs } \\
\text { (up to more than a million) in a single sample. Used in the genome-wide association studies. }\end{array}$ \\
\hline RNA/cDNA microarrays & $\begin{array}{l}\text { Used in gene expression analyses by quantify amounts of transcripts in a single sample or in } \\
\text { comparison between two samples. Useful for the quantification of big number of different } \\
\text { transcripts (also genome-wide) in single samples. }\end{array}$ \\
\hline PCR & PCR, basic technique in almost all current pharmacogenetic and genomic analysis \\
\hline qPCR (real-time PCR) & $\begin{array}{l}\text { Detection of the PCR product formation while PCR reaction proceeds using various fluorescence } \\
\text { quenching (TaqMan }{ }^{\mathbb{R}} \text { ) or fluorescence energy transfer }\left(\text { Light-Cycler }^{\mathbb{R}}\right) \text { techniques for } \\
\text { genotyping of single SNPs in many samples. }\end{array}$ \\
\hline $\begin{array}{l}\text { qRT-PCR (quantitative reverse transcriptase } \\
\text { PCR) }\end{array}$ & $\begin{array}{l}\text { Used to quantify amounts of transcripts in a sample after a reverse transcription reaction. Useful } \\
\text { for quantification of RNAs in big numbers of samples. }\end{array}$ \\
\hline
\end{tabular}

ber of interactions will have to be considered, and the numbers of factors and variables to be analysed in transcriptomics, metabolomics and other broad approaches are not smaller. These interactions may be quite complex partially antagonistic, partially superadditive - and they surely will not be limited to interactions between two genes respectively, but there will be interactions between multiple genes. The amount of epigenetic variation is even bigger, since the patterns differ between tissues and ages of the individual. Thus, the development of bioinformatics and genetic statistics plays a crucial role in the further development of pharmacogenetics and genomics. There are too many variations and interactions to be experimentally studied, and we urgently need methods to identify those variants which are biologically relevant.

Some approaches to identify the - potentially - most relevant regions in the genome have already evolved and can be further developed. Since the first interspecies comparisons of haemoglobin, protein sequences homology search has been an important tool to identify those segments in the genome that are particularly crucial for the biological function of a certain protein. Linkage of genetic variants on the same chromosome is a central basis of methods in genetic statistics. If a person has a certain variant at a certain position, the same person will probably also have other linked variants 10,000 or 50,000 bp nearby, and the same constellation will be found in several relatives of this person. This linkage is illustrated by red or orange rhombes in the lower part of Fig. 4, which shows the haplotype structure at the cytochrome P450 2C9 gene locus.

The impact of this linkage was taken into consideration in earlier research, such as in describing genetic variation in cytochrome P450 variants [136], and it has been expanded to a genome-wide approach with the human haplotype map project [90] (www.hapmap.org). It has become apparent that there are recombination hotspots and haplotype blocks, i.e. regions of tight linkage, as indicated by the large, almost entirely red triangular regions in Fig. 5. Knowledge about such linkage may greatly facilitate genotyping since from all completely linked polymorphisms only one has to be analysed. One can concentrate on the so-called tagging SNPs and still know a lot about all of the variants because all the other variants are linked. Based on a selection of typed variants, it is possible to input a larger number of variants into each individual's genome and thereby have a very high density map of genetic markers [137].

While the variants are arranged in the chromosomes in a linear chain, we now recognize them as being arranged in socalled haplotype blocks within which there are dozens, hundreds or even thousands of variants relatively tightly 


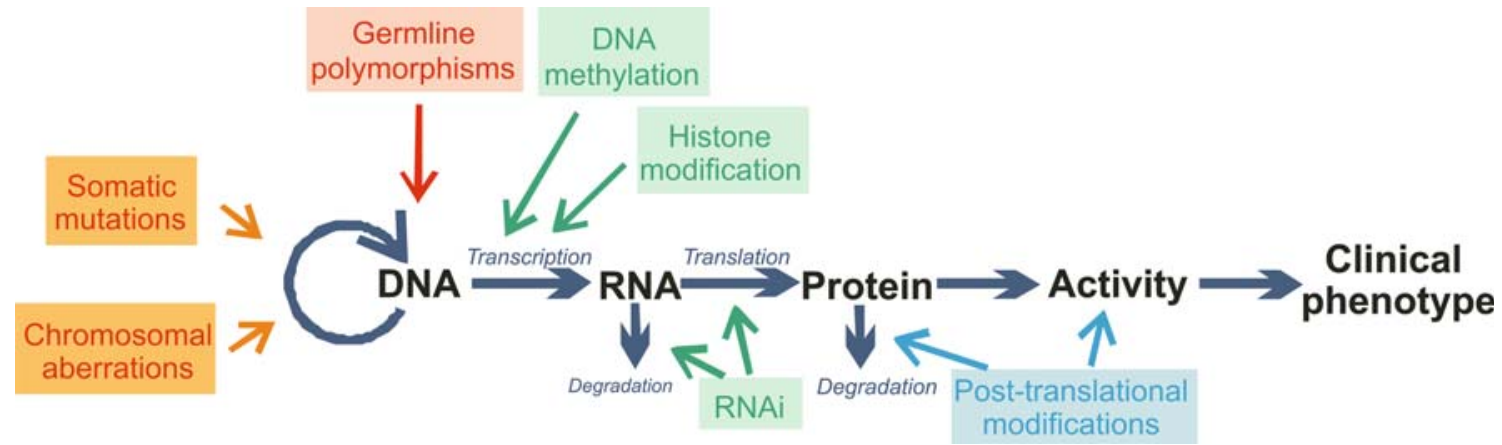

Fig. 4 Relationship between genomic variation, variation in RNA and protein expression and the biological effects and clinical effects. Some but not all - mechanisms of regulation are also indicated

\section{Data Source}

HopMop Data Rel 21 a/phosell Jan07, on NC81 B35 assembly, dbSNP b125 ح

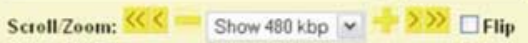

Population descriptors:YRI: Youba in Ibadan, Nigeria, JPT: Japanese in Tokyo, Japan, CHB: Han Chinese in Beijing. China, CEU: CEPH (Utah residents with ancestry from northem and western Europe

日 Overview

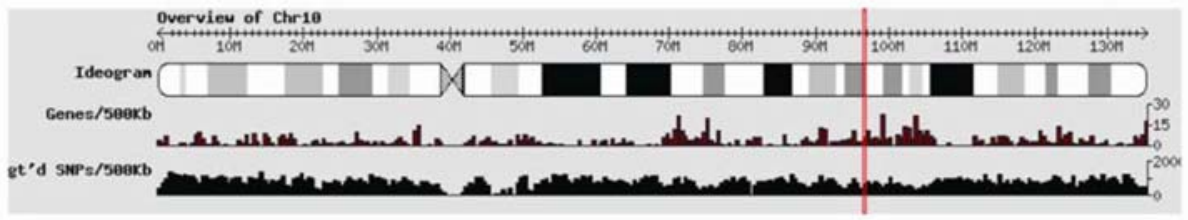

日eqien

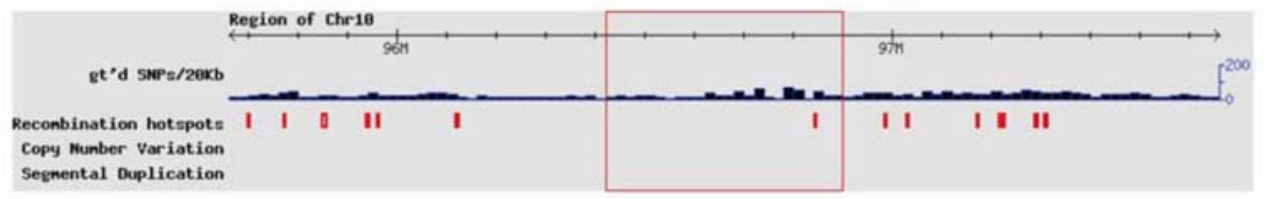

日etails

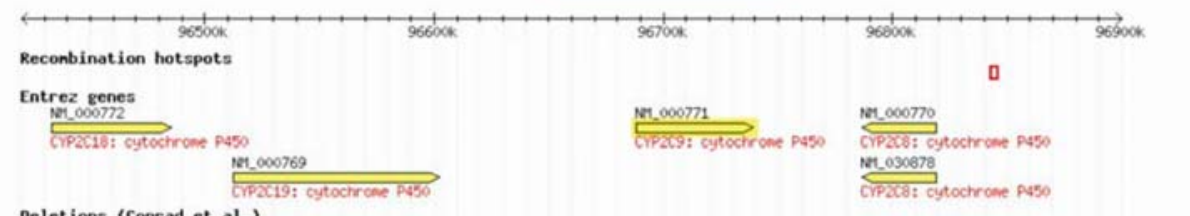

Deletions (Conrad et al.)

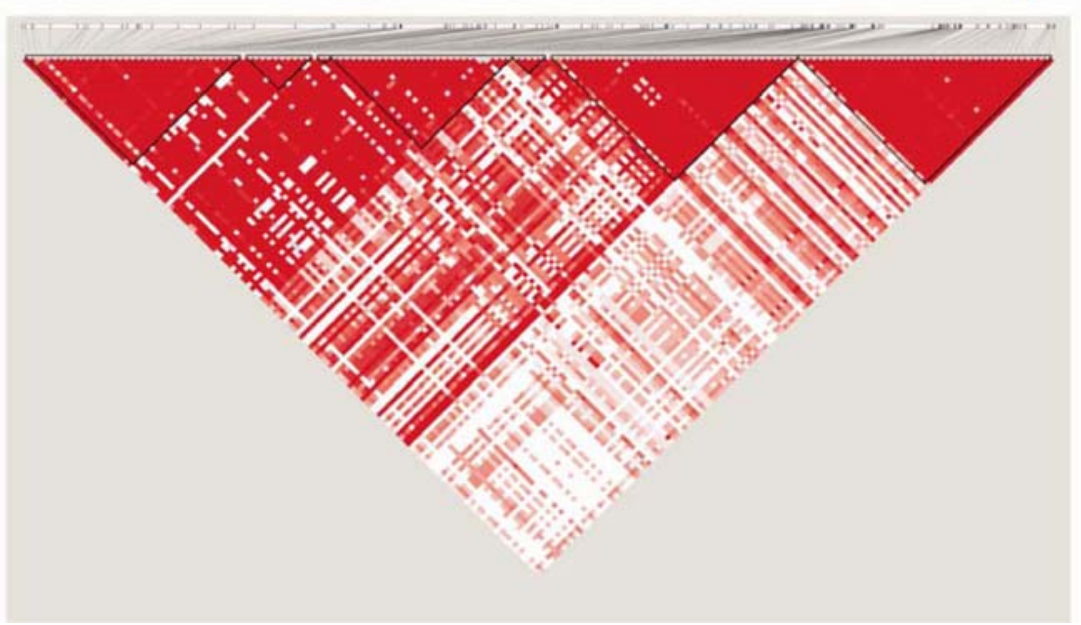

Fig. 5 Illustration of gene arrangement and haplotype structure of the CYP2C gene locus viewed by the HapMap database. The 480,000-bp region from the long arm of chromosome 10 shown here includes the genes CYP2C18, CYP2C19, CYP2C8 and CYP2C8 (shown as yellow arrows in the middle). The linkage disequilibrium (LD) pattern of the 546 SNPs recorded in the HapMap database and located in this is shown as red-coloured rhombes at the bottom of the picture. The depth of the red colour indicates the strength of the pairwise LD, varying from deep red for full $\mathrm{LD}\left(\mathrm{D}^{\prime}=1\right)$ to white for no $\mathrm{LD}$ existing $\left(D^{\prime}=0\right)$. The picture is produced using HapMap database (www. hapmap.org, [90, 138]) and the HAPLOVIEW software [139] 
coupled. Outside the haplotype blocks or between haplotypes blocks there is only relatively sparse linkage. Systematic analysis of the length of the specific linkage blocks may be informative in terms of the functional and evolutionary role of specific variants and haplotypes. An extended haplotype homozygosity is considered to indicate those variants which are selected in recent evolution. Thus, this analysis may greatly help to identify the really important variants among the more than 12 million SNPs in the human genome. However, as yet there is no convincing prospective validation of this approach (Table 6).

It is immediately evident that disease risk and response to drugs may depend on the combinations of several genes, and years ago scientists and companies emerged with the concept to sell predictive marker combinations. However, it is all too easy to identify in each study predictive marker combinations which are more predictive than the single markers alone. The aim, however, is to identify predictive marker combinations which remain predictive beyond the study in which they were identified.
Predictive marker combinations may be identified as interaction terms in cross-tabulations, analyses of variance or logistic regression analyses, and data mining tools, such as recursive partitioning, are particularly helpful for this. The situations in which such recursive partitioning should be performed in whole genome scans is not yet clear: in the entire data sets or, as some authors have performed [140], in subsets identified in a monofactorial analysis as possible risk factors.

Hypothesis-free genome-wide association studies

\section{Disease risk studies}

The vast majority of pharmacogenetic studies that have been completed thus for used the so called the candidate gene approach. That means that those genes were analyzed from which the investigators assumed that they may be relevant according to biological reasoning. The alternative, genomewide linkage analysis, was only rarely applied in pharmacogenetics. This approach was successfully applied in linkage

Table 6 Bioinformatics databases and software tools for pharmacogenetics and genomics

\begin{tabular}{|c|c|c|}
\hline Aim & Computer solution & Website \\
\hline \multicolumn{3}{|l|}{ Databases } \\
\hline \multirow[t]{2}{*}{ Human genome } & $\begin{array}{l}\text { National Center for Biotechnology } \\
\text { Information in USA (NCBI) }\end{array}$ & www.ncbi.nlm.nih.gov/genome/guide/human/ \\
\hline & Ensembl & www.ensembl.org/Homo_sapiens/ \\
\hline \multirow[t]{2}{*}{ SNP databases } & dbSNP at NCBI & www.ncbi.nlm.nih.gov/SNP/ \\
\hline & Japan database JSNP & http://snp.ims.u-tokyo.ac.jp/ \\
\hline $\begin{array}{l}\text { Pairwise linkage disequilibrium } \\
\text { and haplotypes }\end{array}$ & HapMap project & www.hapmap.org \\
\hline Gene expression analysis & $\begin{array}{l}\text { Gene Expression Omnibus (GEO) by } \\
\text { NCBI }\end{array}$ & www.ncbi.nlm.nih.gov/geo/ \\
\hline Metabolic pathways & $\begin{array}{l}\text { Kyoto Encyclopedia of Genes and } \\
\text { Genomes (KEGG) }\end{array}$ & www.genome.jp/kegg/ \\
\hline \multicolumn{3}{|l|}{ Software } \\
\hline Homology search & BLAST at NCBI & www.ncbi.nlm.nih.gov/BLAST/ \\
\hline $\begin{array}{l}\text { Sequence alignment and } \\
\text { identification of new SNPs }\end{array}$ & Gap4 (part of Staden package) & http://staden.sourceforge.net/ \\
\hline Haplotype mapping (phasing) & Phase, Fastphase & $\begin{array}{l}\text { http://stephenslab.uchicago.edu/software.html (there is also a } \\
\text { new program for imputation of analyzed to in-silico linked } \\
\text { SNPs) }\end{array}$ \\
\hline $\begin{array}{l}\text { Pairwise linkage disequilibrium } \\
\text { and visualization of Haplotype } \\
\text { blocks }\end{array}$ & Haploview & www.broad.mit.edu/mpg/haploview/ \\
\hline $\begin{array}{l}\text { Extended haplotype homozygosity } \\
\text { (EHH) }\end{array}$ & Sweep & www.broad.mit.edu/mpg/sweep/ \\
\hline $\begin{array}{l}\text { Analysis of SNPs affecting } \\
\text { promoter function }\end{array}$ & TRANSFAC & http://transfac.bioinf.med.uni-goettingen.de/ \\
\hline \multirow[t]{2}{*}{$\begin{array}{l}\text { Analysis of SNPs affecting splice } \\
\text { sites and ESEs }\end{array}$} & $\begin{array}{l}\text { Automated Splice Site Analyses } \\
\text { (Children's Mercy Hospitals } \\
\text { Missouri, USA) }\end{array}$ & https://splice.cmh.edu/ \\
\hline & $\begin{array}{l}\text { ESEfinder } 3.0 \text { (Cold Spring Harbor } \\
\text { Laboratory) }\end{array}$ & $\begin{array}{l}\text { http://rulai.cshl.edu/cgi-bin/tools/ESE3/esefinder.cgi? } \\
\text { process=home }\end{array}$ \\
\hline
\end{tabular}


studies of families to map the causal mutation for many mono-genetic diseases, and sets of several hundreds of genome-wide VNTR markers were sufficient to identify loci such as the BRCA1 locus or the cystic fibrosis gene locus.

The approach of a genome-wide association study of unrelated individuals started only very recently to become a successful approach in identifying medically relevant polymorphisms. That approach became successful after investigators became technically able to genotype sufficient numbers of single nucleotide polymorphisms and subjects [141]. Even the first genome-wide microarrays probing "only" 10,000 SNPs may be useful in family studies, but we are not aware of a successful application in association studies with unrelated cases and controls. Microarrays probing for 500,000 or $1,000,000$ SNP markers equally distributed in a single human genome now enable such studies. A more economic approach appears to be that of testing for haplotype-tagging SNPs, and several studies (Table 7) have used this approach with 300,000 haplotypetagging SNPs.

One of the first success stories of genome-wide SNP analysis was the identification of the complement factor $\mathrm{H}$ (CFH) His402Tyr polymorphisms as the susceptibility factor for macula degeneration with an odds ratio above 7 for homozygous carriers of the variant [142]. This study comprised only 96 cases, and 50 controls, who were analysed for 116,204 SNPs; the results were subsequently confirmed by two other studies and are in agreement with linkage data of the locus obtained earlier in family studies [143-146]. A similar story proving the success of genomewide association studies is the identification of the genetic polymorphism underlying a frequent subtype of open-angle glaucoma, the so-called exfoliation glaucoma [147] and gallstone disease. According to this data, a certain haplotype from two non-synonymous variants in the gene or a single SNP conferred more than a 30 -fold and sevenfold increased risk for the disease, respectively [148]. Unfortunately, these cases are not representative of other multifactorial diseases, and odds ratios of 7 or 30 for single genes cannot typically be expected in polygenetic diseases. However, odds ratios between 1.0 and 2.0 found in many recently published genome-wide association studies (Table 7) raise a number of questions concerning the causal relationship behind these findings and concerning the medical relevance of these findings.

Some genome-wide analyses of polygenetic disease are summarized in Table 7 [140, 148, 151, 154, 156, 157]. The largest study included 14,000 patients suffering from seven diseases and 3000 common controls [156]. The study was planned to have sufficient power to detect associations with an odds ratio as low as 1.5 , and these studies suggested a number of previously unknown and unexpected susceptibility loci and susceptibility genes (Table 7). Most interestingly, some of the identified susceptibility loci were common for different diseases, indicating a common etiology [151, 156158]. As seen in column 2 of Table 7, a most important priority in many of the genome-wide association studies was to obtain as many subjects as possible, apparently to avoid the risk of a too low power. However, study design issues are not less important than statistical power to terms of obtaining reliable and reproducible data $[159,160]$.

In addition, several general questions regarding these types of analyses have been addressed. Most importantly, a replication strategy became almost standard in these studies [161], which was probably the lesson also learned from studies carried out 20 years which obtained many irreproducible data in pharmacogenetic and genomic disease association research. The ability to replicate is the essential step justifying further work on the finding, but it does not exclude some types of systematic error. In addition, at least as important as the false positive data are the false negative data, and the number of truly medically relevant gene variant not identified in studies, such as those listed in Table 7, may be quite large although we cannot precisely calculate this amount of false negative findings. Replication or lack of replication of gene-disease association data is a central open question in this type of research. Reasons behind this include unresolved multiple testing issues but also complex gene-gene and gene-environment interaction which may differ depending on ethnicity, time-frame, location of the study and many other factors.

It is interesting to note that a number of significant loci were ultimately identified in almost all studies. Nevertheless, we would not consider genome-wide association studies as the recipe of guaranteed success. Because of the known phenomenon of publication bias, we cannot assume that all such genome-wide studies with sufficient power are publicly available. It is notable, however, that there was one negative sub-study listed in Table 7. As the authors noted, there were no signals with significance below $5 \times 10^{-7}$, but there were multiple signals with $p$ between $10^{-4}$ and $10^{-7}$. The authors explained the failure to find a significant association in their study by a study design that was not optimal for hypertension, by still existing limitations of the tested variants and by possible multifactorial causation of hypertension which cannot yet be uncovered by the applied approaches [149].

As indicated in Table 7, many of the odds ratios identified in genome-wide association studies for specific diseases were far too small to be relevant for individual decision-making in the therapy of patients but may give new insights into the diseases. Thus far, most genome-wide analyses have dichotomized their dependent variable into cases and controls, which may result in a significant loss of power and particularly for phenotypes related to drug dosage quantitative trait analyses are needed. 
Table 7 Summary of some genome-wide disease association studies

\begin{tabular}{|c|c|c|c|c|c|c|c|}
\hline Disease & $\begin{array}{l}\text { Sample size N } \\
\text { cases/controls }\end{array}$ & Technique $^{\mathrm{a}}$ & $\begin{array}{l}\text { Locus (gene) } \\
\text { identified }\end{array}$ & $\begin{array}{l}\text { Polymorphism } \\
\text { identified }\end{array}$ & $\mathrm{PNSG}^{\mathrm{b}}$ & $\begin{array}{l}\text { Odds ratio ( } 95 \% \\
\text { confidence intervals) }^{\mathrm{c}}\end{array}$ & References \\
\hline $\begin{array}{l}\text { Bipolar } \\
\text { disorder }\end{array}$ & $1868 / 2938$ & A500k & $16 \mathrm{p} 12$ & rs420259 & Yes & $2.07(1.6-2.69)$ & [149] \\
\hline $\begin{array}{l}\text { Coronary } \\
\text { artery disease }\end{array}$ & $1926 / 2938$ & A500k & 9 p21 & rs1333049 & No & $1.90(1.61-2.24)$ & [149] \\
\hline \multirow{10}{*}{$\begin{array}{l}\text { Crohn’s } \\
\text { disease }\end{array}$} & \multirow[t]{10}{*}{$1748 / 2938$} & \multirow[t]{10}{*}{ A500k } & NOD2 & rs 17221417 & Yes & $1.92(1.58-2.34)$ & \multirow[t]{10}{*}{ [149] } \\
\hline & & & IL23R & rs11209026 & Yes & $1.86(1.54-2.24)$ & \\
\hline & & & $2 \mathrm{q} 37$ & rs 10210302 & No & $1.85(1.56-2.21)$ & \\
\hline & & & BSN & rs9858542 & No & $1.84(1.49-2.26)$ & \\
\hline & & & $5 \mathrm{p} 13.1$ & rs 17234657 & No & $2.32(1.59-3.39)$ & \\
\hline & & & IRGM & rs 1000113 & No & $1.92(0.92-4.00)$ & \\
\hline & & & $10 \mathrm{q} 21$ & rs 10761659 & No & $1.55(1.3-1.84)$ & \\
\hline & & & NKX2-3 & rs 10883365 & No & $1.62(1.37-1.92)$ & \\
\hline & & & $16 q 12$ & rs 17221417 & No & $1.92(1.58-2.34)$ & \\
\hline & & & PTPN2 & rs 2542151 & No & $2.01(1.46-2.76)$ & \\
\hline Hypertension & $1952 / 2938$ & A500k & None & & & & [149] \\
\hline \multirow{3}{*}{$\begin{array}{l}\text { Rheumatoid } \\
\text { arthritis }\end{array}$} & \multirow[t]{3}{*}{$1860 / 2938$} & \multirow[t]{3}{*}{ A500k } & PTPN22 & rs6679677 & Yes & $3.32(1.93-5.69)$ & \multirow[t]{3}{*}{ [149] } \\
\hline & & & HLA-DRB1 & rs6457617 & Yes & $5.21(4.31-6.30)$ & \\
\hline & & & $7 q 32$ & rs11761231 & No & $1.64(1.35-1.99)$ & \\
\hline \multirow{5}{*}{$\begin{array}{l}\text { Type } 1 \\
\text { diabetes }\end{array}$} & \multirow[t]{5}{*}{$1963 / 2938$} & \multirow[t]{5}{*}{ A500k } & PTPN22 & rs6679677 & Yes & $5.19(3.15-8.55)$ & \multirow[t]{5}{*}{ [149] } \\
\hline & & & HLA-DRB1 & rs9272346 & Yes & $18.5(12.7-27.0)$ & \\
\hline & & & $12 \mathrm{q} 13$ & rs11171739 & No & $1.75(1.48-2.06)$ & \\
\hline & & & $12 \mathrm{q} 24$ & rs 17696736 & No & $1.94(1.65-2.29)$ & \\
\hline & & & PTPN2 & rs 12708716 & No & $1.55(1.27-1.89)$ & \\
\hline \multirow{3}{*}{$\begin{array}{l}\text { Type } 2 \\
\text { diabetes }\end{array}$} & \multirow[t]{3}{*}{$1924 / 2938$} & \multirow[t]{3}{*}{ A500k } & TCF7L2 & rs 4506565 & Yes & $1.88(1.56-2.27)$ & \multirow[t]{3}{*}{ [149] } \\
\hline & & & CDKAL1 & rs9465871 & No & $2.17(1.60-2.95)$ & \\
\hline & & & FTO & rs9939609 & No & $1.55(1.30-1.84)$ & \\
\hline $\begin{array}{c}\text { Gallstone } \\
\text { disease }\end{array}$ & $2113 / 1965^{\mathrm{d}}$ & A500k & ABCG8 & $\begin{array}{l}\text { rs11887534 } \\
(\mathrm{D} 19 \mathrm{H})\end{array}$ & Yes & $7.10(0.90-158.6)$ & {$[148]$} \\
\hline $\begin{array}{l}\text { Myocardial } \\
\text { Infarction }\end{array}$ & $4587 / 12767^{\mathrm{d}}$ & IH300k & 9 p21 & rs 10757278 & No & $1.64(1.47-1.82)$ & {$[150]$} \\
\hline $\begin{array}{l}\text { Atrial } \\
\text { fibrillation }\end{array}$ & $2801 / 17714^{\mathrm{d}}$ & IH300k & $4 \mathrm{p} 25$ & rs2200733 & & $1.68(1.53-1.83)^{\mathrm{e}}$ & {$[151]$} \\
\hline \multirow{10}{*}{$\begin{array}{l}\text { Type } 2 \\
\text { diabetes }\end{array}$} & \multirow[t]{10}{*}{$2376 / 2432^{\mathrm{d}}$} & \multirow[t]{10}{*}{ IH300k } & PPARG & rs1801282 & Yes & $1.20(1.07-1.33)$ & \multirow[t]{10}{*}[140]{} \\
\hline & & & SLC30A8 & rs 13266634 & Yes & $1.18(1.09-1.29)$ & \\
\hline & & & HHEX & rs1111875 & Yes & $1.10(1.01-1.19)$ & \\
\hline & & & TCF7L2 & rs7903146 & Yes & $1.34(1.21-1.49)$ & \\
\hline & & & KCNJ11 & rs5219 & Yes & $1.11(1.02-1.21)$ & \\
\hline & & & IGF2BP2 & rs4402960 & No & $1.18(1.08-1.28)$ & \\
\hline & & & CDKAL1 & rs 7754840 & No & $1.12(1.03-1.22)$ & \\
\hline & & & $9 \mathrm{p} 21$ & rs 10811661 & No & $1.20(1.07-1.36)$ & \\
\hline & & & Chr11 & rs9300039 & No & $1.48(1.28-1.71)$ & \\
\hline & & & FTO & rs8050136 & No & $1.11(1.02-1.20)^{\mathrm{e}}$ & \\
\hline \multirow{8}{*}{$\begin{array}{l}\text { Type } 2 \\
\text { diabetes }\end{array}$} & $6529 / 7252^{\mathrm{d}}$ & A500k & SLC30A8 & rs 13266634 & Yes & $1.07(1.00-1.16)$ & {$[152]$} \\
\hline & & & HHEX & rs 1111875 & Yes & $1.14(1.06-1.22)$ & \\
\hline & & & TCF7L2 & rs7903146 & Yes & $1.38(1.31-1.46)$ & \\
\hline & & & KCNJ11 & rs5219 & Yes & $1.15(1.09-1.21)$ & \\
\hline & & & PPARG & rs 1801282 & Yes & $1.09(1.01-1.16)$ & \\
\hline & & & 9 p21 & rs 10811661 & No & $1.20(1.12-1.28)$ & \\
\hline & & & IGF2BP2 & rs4402960 & No & $1.17(1.11-1.23)$ & \\
\hline & & & CDKAL1 & rs 7754840 & No & $1.08(1.03-1.14)^{\mathrm{e}}$ & \\
\hline Rheumatoid & $1522 / 1850$ & $\mathrm{IH} 300$ & TRAF1 & rs3761847 & No & $1.32(1.23-1.42)^{\mathrm{e}}$ & {$[153]$} \\
\hline arthritis & & IH550 & & & & & \\
\hline $\begin{array}{l}\text { Exfoliation } \\
\text { Glaucoma }\end{array}$ & $290 / 14672^{d}$ & IH300 & LOXL1 & $\begin{array}{c}\text { rs1048661+ } \\
\text { rs3825942 }\end{array}$ & No & $27.05(14.9-49.2)$ & {$[147]$} \\
\hline
\end{tabular}


Table 7 (continued)

\begin{tabular}{|c|c|c|c|c|c|c|c|}
\hline Disease & $\begin{array}{l}\text { Sample size N } \\
\text { cases/controls }\end{array}$ & Technique $^{\mathrm{a}}$ & $\begin{array}{l}\text { Locus (gene) } \\
\text { identified }\end{array}$ & $\begin{array}{l}\text { Polymorphism } \\
\text { identified }\end{array}$ & $\mathrm{PNSG}^{\mathrm{b}}$ & $\begin{array}{l}\text { Odds ratio }(95 \% \\
\text { confidence intervals) }\end{array}$ & References \\
\hline Breast cancer & $4398 / 4316^{\mathrm{d}}$ & $\begin{array}{l}\text { Custom } \\
\text { array }\end{array}$ & $\begin{array}{l}\text { FGFR2 } \\
\text { TNRC9 } \\
\text { TNRC9 } \\
\text { MAP3K1 } \\
\text { LSP1 } \\
\text { H19 } \\
\text { 8q }\end{array}$ & $\begin{array}{l}\text { rs2981582 } \\
\text { rs12443620 } \\
\text { rs8051542 } \\
\text { rs889312 } \\
\text { rs3817198 } \\
\text { rs2107425 } \\
\text { rs } 13281615\end{array}$ & $\begin{array}{l}\text { No } \\
\text { No } \\
\text { No } \\
\text { No } \\
\text { No } \\
\text { No } \\
\text { No }\end{array}$ & $\begin{array}{l}1.63(1.52-1.72) \\
1.23(1.17-1.30) \\
1.19(1.12-1.27) \\
1.27(1.19-1.36) \\
1.17(1.08-1.25) \\
0.95(0.89-1.01) \\
1.18(1.10-1.25)\end{array}$ & [154] \\
\hline $\begin{array}{l}\text { Colorectal } \\
\text { cancer }\end{array}$ & $7334 / 5246^{\mathrm{d}}$ & IH550 & $8 \mathrm{q} 24$ & rs6983267 & & $1.47(1.34-1.62)$ & {$[155]$} \\
\hline
\end{tabular}

\footnotetext{
${ }^{a}$ A, Affymetrix; IH, illumina haplotype tagging array

${ }^{\mathrm{b}}$ Previously known susceptibility gene or locus

${ }^{\mathrm{c}}$ Unless mentioned otherwise, all odds ratios refer to the relative risks of homozygous variant carriers compared to homozygous wild-type carriers

${ }^{\mathrm{d}}$ Initial genome-wide screens were performed only with a subset of the sample sizes given here for the final analysis

${ }^{\mathrm{e}}$ Odds ratio for the presence versus absence of risk allele (allelic odds ratio)
}

\section{Drug-therapy response studies}

The genome-wide disease association studies may provide important hints for planning the next generation of clinical pharmacogenomic studies in which we want to identify genomic markers predicting therapy response or adverse events. A number of issues have to be carefully considered here. One problem in many drug response studies (but mostly not in studies on adverse drug events) is the ability to distinguish between drug response and different forms of the natural course of the disease. This is a particular problem in diseases with a naturally variable course, such as ulcer or depression. The only formally correct solution would be to compare episodes without treatment with treatment episodes within individuals, but this is ethically not possible. A comparison of response to differently acting treatments might reveal important insights.

Where should we go?

After more than 40 years of pharmacogenetic and pharmacogenomic research, we now have a multitude of options. The highlights of the year 2007 were numerous large genome-wide association studies, and data obtained from some of these studies will result in optimized medical therapies. However, more than before, pharmacogenetics and genomics research remains an iterative process (Fig. 6), and there is much room for opportunities for improvement in each of the approaches. Viewed from the perspective of clinical pharmacologist, research should start with a welldefined and well-designed clinical study and should finally end with improvements for the patients.

However, between the start and the end we have to apply a lot of molecular and information sciences. A constant pattern in pharmacogenetic research from early CYP2D6cancer association studies to recent genome-wide associa- tion studies is that genetic polymorphisms apparently correlate with medical phenotypes, but it remains obscure precisely how the polymorphisms may do that. So there is a demand to distinguish between those associations which are true and leading to definitive results and those which are not - and we have to elucidate the underlying mechanisms. As yet, this demand has not been met.

To this end, human pharmacology studies are well suited, but ex vivo research using human cells can also be applied. For example, cell lines from genetically unrelated individuals representing different organs and tissues may significantly help in the functional validation of SNPs identified in clinical genetic-phenotypic association studies [162]. Lymphoblastoid cell lines and fibroblasts from the participants of the HapMap Project, which are already genotyped for more than 4,000,000 SNPs (Coriell cell repositories, http://ccr.coriell.org/) are nowadays worldwide in use to do just such research. In contrast to experiments with primary cells, these cells enable repetitive measurements with all of the different genotypes at the same time and with greatly improved possibilities for inter-laboratory validation. Of course, there are also limitations due to artifacts that potentially arise from cell culture or from immortalization procedures, and other cell types are needed, but the principle is moving forward. Without having been spectacularly new in the public mind, in vitro approaches nevertheless have already significantly changed clinical pharmacology. For example, drug-drug interactions can not be quite precisely predicted based on in vitro drug metabolism studies, and clinical proband studies are more a final confirmation rather than an initial search, as it was 40 years ago. Similar approaches are developing in drug transporter research and in pharmacodynamics research concerning intended and adverse drug effects, such as longQT producing effects at the HERG (KCNH2) channel [163] (Table 8). 


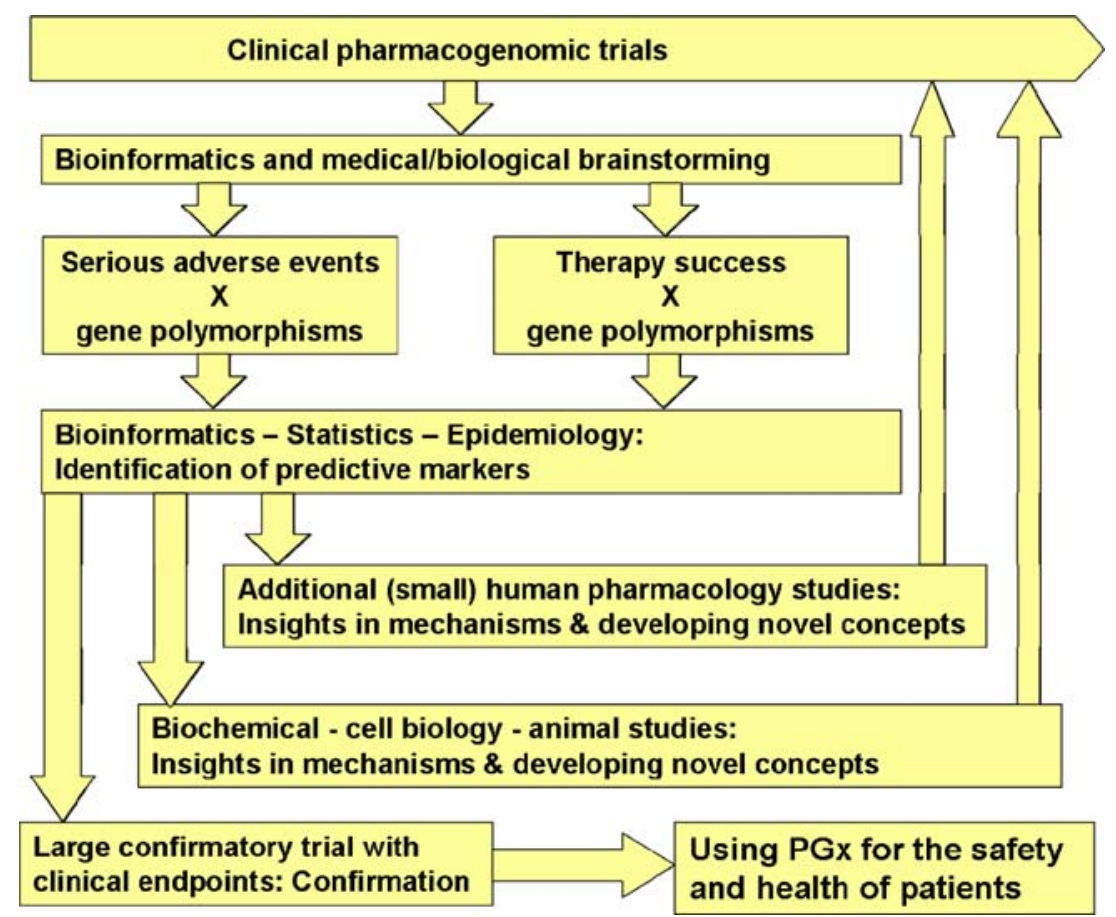

Fig. 6 The pathways of pharmacogenetic and pharmacogenomic research. The routes shown here may not be the only ones, but the figure should illustrate how multiple approaches have to be combined to obtain pharmacogenomic knowledge that is of value for the development of new therapeutics or for the improvement of existing therapies

Table 8 Theses summarizing the present review

Drug effects

1. If the safety or efficacy of a drug may depend on genetic polymorphisms, the best choices are either to delete the drug from the market or to analyse and consider the genetic polymorphism in therapy.

2. Pharmacogenetics and genomics are a most important reason behind interethnic differences in drug effects. Thus, pharmacogenetics has to be carefully studied in worldwide marketing of drugs and in pharmacovigilance

3. Many pharmacogenetic polymorphisms may have both positive and negative consequences for human health depending on the context and exposures

4. Applying pharmacogenetic knowledge in the clinics should not always mean applying genotyping, often some type of phenotyping may be superior (e.g. concerning G6PDH, BCHE, TPMT, DPD).

5. Every clinical pharmacologist should know about the background and clinical consequences of genetic polymorphisms in G6PDH, BCHE, NAT2, CYP2D6, CYP2C19, CYP2C9, TPMT, DPD, UGT1A1, VKORC1 and factor V; very soon that list may have to be updated.

6. As with many complex and new technologies, there are problems and delays in the transfer of scientific pharmacogenetic knowledge to the bedside. Specific translational research has to be supported.

7. Prospective evaluation studies on the clinical value of pharmacogenetic diagnostics are needed to proof the concept of pharmacogenetic diagnostics. But in many areas of drug therapy such studies are not feasible; in such cases, the pharmacogenetic diagnostics will have to be based on scientifically valid mechanistic reasoning and appropriate clinical monitoring.

8. In addition to concentrating on single genes, pharmacogenetic and genomic pathway research is required to understand the causes behind pharmacokinetic and pharmacodynamic inter-individual variation.

9. Because of the mass of pharmacogenetic information, medical information technologies including bioinformatics are essential in the future of clinical pharmacology and clinical pharmacogenetics.

10. Besides the traditional axis between genes - mRNAs - proteins and functions, other mechanisms, such as epigenetics and RNAi, are apparently relevant for understanding of interindividual variation in drug effects and adverse effects.

11. SNP-based genome-wide association studies have proven their value, and new insights have been obtained for instance concerning gallstone disease, open angle glaucoma and macula degeneration.

12. The future of pharmacogenetic and genomic research will be a mixture of genome-wide SNP and expression analysis in appropriately designed clinical studies, and this will have to be combined with in vitro and ex vivo pharmacogenomic research with human cells and model organisms and with human pharmacological research. Finding the right combination of research tools may be the most important demand. 
In terms of research priorities, genetically determined aberrations in signal transduction pathways may be most exciting new option, and these have already been identified in many types of cancer. However, thus far there is only relatively little data on the impact of frequently inherited polymorphisms in intracellular signal transduction pathways. Apparently, despite the requirements for professional specialization, a combined view on genomics, transcriptomics, proteomics, epigenomics, metabolics and clinical requirements [164] is needed.

Open Access This article is distributed under the terms of the Creative Commons Attribution Noncommercial License which permits any noncommercial use, distribution, and reproduction in any medium, provided the original author(s) and source are credited.

\section{References}

1. Garrod AE (1902) The incidence of alkaptonuria: a study in chemical individuality. Lancet 2:1616-1620

2. Earle DP, Bigelow FS, Zubrod CG, Kane CA (1948) Studies on the Chemotherapy of the Human Malarias. I0. Effect of Pamaquine on the blood cells of man. J Clin Invest 27:121-129

3. Childs B, Zinkham WH, Browne EA et al (1958) A genetic study of a defect in glutathione metabolism of the erythrocyte. Bull Johns Hopkins Hosp 1-2:21-37

4. Kalow W, Meyer UA, Tyndale R (2005) Pharmacogenomics, 2nd edn. Taylor \& Francis, Oxford

5. Kalow W (1982) Ethnic differences in drug metabolism. Clin Pharmacokinet 7:373-400

6. Kalow W (1952) Butyrylcholine esterase in the blood serum of man and animal. Naunyn Schmiedebergs Arch Exp Pathol Pharmakol 215:370-377

7. Bönicke R, Lisboa BP (1957) Über die Erbeddingtheit der intraindividuellen Konstanz der Isoniazidausscheidung beim Menschen. Naturwissenschaften 44:314

8. Evans DA, Manley KA, Mc KV (1960) Genetic control of isoniazid metabolism in man. Br Med J 2:485-491

9. Blum M, Grant DM, McBride W, Heim M, Meyer UA (1990) Human arylamine $\mathrm{N}$-acetyltransferase genes: isolation, chromosomal localization, and functional expression. DNA Cell Biol 9:193-203

10. Cascorbi I, Drakoulis N, Brockmöller J, Maurer A, Sperling K, Roots I (1995) Arylamine N-acetyltransferase (NAT2) mutations and their allelic linkage in unrelated Caucasian individuals: correlation with phenotypic activity. Am J Hum Genet 57:581-592

11. Kinzig-Schippers M, Tomalik-Scharte D, Jetter A, Scheidel B, Jakob V, Rodamer M, Cascorbi I, Doroshyenko O, Sorgel F, Fuhr U (2005) Should we use N-acetyltransferase type 2 genotyping to personalize isoniazid doses? Antimicrob Agents Chemother 49:1733-1738

12. Eichelbaum M, Spannbrucker N, Steincke B, Dengler HJ (1979) Defective N-oxidation of sparteine in man: a new pharmacogenetic defect. Eur J Clin Pharmacol 16:183-187

13. Mahgoub A, Idle JR, Dring LG, Lancaster R, Smith RL (1977) Polymorphic hydroxylation of Debrisoquine in man. Lancet 2:584-586

14. Gonzalez FJ, Skoda RC, Kimura S, Umeno M, Zanger UM, Nebert DW, Gelboin HV, Hardwick JP, Meyer UA (1988) Characterization of the common genetic defect in humans deficient in debrisoquine metabolism. Nature 331:442-446
15. Kimura S, Umeno M, Skoda RC, Meyer UA, Gonzalez FJ (1989) The human debrisoquine 4-hydroxylase (CYP2D) locus: sequence and identification of the polymorphic CYP2D6 gene, a related gene, and a pseudogene. Am J Hum Genet 45:889-904

16. Heim M, Meyer UA (1990) Genotyping of poor metabolisers of debrisoquine by allele-specific PCR amplification. Lancet 336:529-532

17. Ingelman-Sundberg M (2005) Genetic polymorphisms of cytochrome P450 2D6 (CYP2D6): clinical consequences, evolutionary aspects and functional diversity. Pharmacogenomics J 5:6-13

18. Johansson I, Lundqvist E, Bertilsson L, Dahl ML, Sjoqvist F, Ingelman-Sundberg M (1993) Inherited amplification of an active gene in the cytochrome P450 CYP2D locus as a cause of ultrarapid metabolism of debrisoquine. Proc Natl Acad Sci USA 90:11825-11829

19. Sachse C, Brockmöller J, Bauer S, Roots I (1997) Cytochrome P450 2D6 variants in a Caucasian population: allele frequencies and phenotypic consequences. Am J Hum Genet 60:284-295

20. Rendic S (2002) Summary of information on human CYP enzymes: human P450 metabolism data. Drug Metab Rev 34:83-448

21. Goetz MP, Rae JM, Suman VJ, Safgren SL, Ames MM, Visscher DW, Reynolds C, Couch FJ, Lingle WL, Flockhart DA, Desta Z, Perez EA, Ingle JN (2005) Pharmacogenetics of tamoxifen biotransformation is associated with clinical outcomes of efficacy and hot flashes. J Clin Oncol 23:9312-9318

22. Kirchheiner J, Heesch C, Bauer S, Meisel C, Seringer A, Goldammer M, Tzvetkov M, Meineke I, Roots I, Brockmöller J (2004) Impact of the ultrarapid metabolizer genotype of cytochrome P450 2D6 on metoprolol pharmacokinetics and pharmacodynamics. Clin Pharmacol Ther 76:302-312

23. Kirchheiner J, Meineke I, Muller G, Roots I, Brockmoller J (2002) Contributions of CYP2D6, CYP2C9 and CYP2C19 to the biotransformation of $\mathrm{E}$ - and Z-doxepin in healthy volunteers. Pharmacogenetics 12:571-580

24. Kirchheiner J, Muller G, Meineke I, Wernecke KD, Roots I, Brockmöller J (2003) Effects of polymorphisms in CYP2D6, CYP2C9, and CYP2C19 on trimipramine pharmacokinetics. J Clin Psychopharmacol 23:459-466

25. Kupfer A, Preisig R (1984) Pharmacogenetics of mephenytoin: a new drug hydroxylation polymorphism in man. Eur J Clin Pharmacol 26:753-759

26. de Morais SM, Wilkinson GR, Blaisdell J, Nakamura K, Meyer UA, Goldstein JA (1994) The major genetic defect responsible for the polymorphism of S-mephenytoin metabolism in humans. J Biol Chem 269:15419-15422

27. De Morais SM, Wilkinson GR, Blaisdell J, Meyer UA, Nakamura K, Goldstein JA (1994) Identification of a new genetic defect responsible for the polymorphism of (S)-mephenytoin metabolism in Japanese. Mol Pharmacol 46:594-598

28. Goldstein JA, Ishizaki T, Chiba K, de Morais SM, Bell D, Krahn PM, Evans DA (1997) Frequencies of the defective CYP2C19 alleles responsible for the mephenytoin poor metabolizer phenotype in various Oriental, Caucasian, Saudi Arabian and American black populations. Pharmacogenetics 7:59-64

29. Sim SC, Risinger C, Dahl ML, Aklillu E, Christensen M, Bertilsson L, Ingelman-Sundberg M (2006) A common novel CYP2C19 gene variant causes ultrarapid drug metabolism relevant for the drug response to proton pump inhibitors and antidepressants. Clin Pharmacol Ther 79:103-113

30. Hulot JS, Bura A, Villard E, Azizi M, Remones V, Goyenvalle C, Aiach M, Lechat P, Gaussem P (2006) Cytochrome P450 2C19 loss-of-function polymorphism is a major determinant of clopidogrel responsiveness in healthy subjects. Blood 108:2244-2247

31. Furuta T, Shirai N, Kodaira M, Sugimoto M, Nogaki A, Kuriyama S, Iwaizumi M, Yamade M, Terakawa I, Ohashi K, 
Ishizaki T, Hishida A (2007) Pharmacogenomics-based tailored versus standard therapeutic regimen for eradication of $H$. pylori. Clin Pharmacol Ther 81:521-528

32. Aithal GP, Day CP, Kesteven PJ, Daly AK (1999) Association of polymorphisms in the cytochrome P450 CYP2C9 with warfarin dose requirement and risk of bleeding complications. Lancet 353:717-719

33. Sullivan-Klose TH, Ghanayem BI, Bell DA, Zhang ZY, Kaminsky LS, Shenfield GM, Miners JO, Birkett DJ, Goldstein JA (1996) The role of the CYP2C9-Leu359 allelic variant in the tolbutamide polymorphism. Pharmacogenetics 6:341-349

34. Blaisdell J, Jorge-Nebert LF, Coulter S, Ferguson SS, Lee SJ, Chanas B, Xi T, Mohrenweiser H, Ghanayem B, Goldstein JA (2004) Discovery of new potentially defective alleles of human CYP2C9. Pharmacogenetics 14:527-537

35. Kidd RS, Curry TB, Gallagher S, Edeki T, Blaisdell J, Goldstein JA (2001) Identification of a null allele of CYP2C9 in an AfricanAmerican exhibiting toxicity to phenytoin. Pharmacogenetics 11:803-808

36. Kirchheiner J, Meineke I, Freytag G, Meisel C, Roots I, Brockmoller J (2002) Enantiospecific effects of cytochrome P450 2C9 amino acid variants on ibuprofen pharmacokinetics and on the inhibition of cyclooxygenases 1 and 2. Clin Pharmacol Ther 72:62-75

37. Kirchheiner J, Meineke I, Steinbach N, Meisel C, Roots I, Brockmoller J (2003) Pharmacokinetics of diclofenac and inhibition of cyclooxygenases 1 and 2: no relationship to the CYP2C9 genetic polymorphism in humans. Br J Clin Pharmacol 55:51-61

38. Kirchheiner J, Stormer E, Meisel C, Steinbach N, Roots I, Brockmöller J (2003) Influence of CYP2C9 genetic polymorphisms on pharmacokinetics of celecoxib and its metabolites. Pharmacogenetics 13:473-480

39. Martin JH, Begg EJ, Kennedy MA, Roberts R, Barclay ML (2001) Is cytochrome P450 2C9 genotype associated with NSAID gastric ulceration? Br J Clin Pharmacol 51:627-630

40. Kirchheiner J, Bauer S, Meineke I, Rohde W, Prang V, Meisel C, Roots I, Brockmöller J (2002) Impact of CYP2C9 and CYP2C19 polymorphisms on tolbutamide kinetics and the insulin and glucose response in healthy volunteers. Pharmacogenetics 12:101-109

41. Kirchheiner J, Brockmoller J, Meineke I, Bauer S, Rohde W, Meisel C, Roots I (2002) Impact of CYP2C9 amino acid polymorphisms on glyburide kinetics and on the insulin and glucose response in healthy volunteers. Clin Pharmacol Ther 71:286-296

42. Kirchheiner J, Meineke I, Muller G, Bauer S, Rohde W, Meisel C, Roots I, Brockmöller J (2004) Influence of CYP2C9 and CYP2D6 polymorphisms on the pharmacokinetics of nateglinide in genotyped healthy volunteers. Clin Pharmacokinet 43:267-278

43. Holstein A, Plaschke A, Ptak M, Egberts EH, El-Din J, Brockmöller J, Kirchheiner J (2005) Association between CYP2C9 slow metabolizer genotypes and severe hypoglycaemia on medication with sulphonylurea hypoglycaemic agents. Br J Clin Pharmacol 60:103-106

44. Kirchheiner J, Brockmöller J (2005) Clinical consequences of cytochrome P450 2C9 polymorphisms. Clin Pharmacol Ther 77:1-16

45. Reynolds KK, Valdes R Jr, Hartung BR, Linder MW (2007) Individualizing warfarin therapy. Personalized Med 4:11-31

46. Weinshilboum RM, Sladek SL (1980) Mercaptopurine pharmacogenetics: monogenic inheritance of erythrocyte thiopurine methyltransferase activity. Am J Hum Genet 32:651-662

47. Schutz E, Gummert J, Mohr F, Oellerich M (1993) Azathioprineinduced myelosuppression in thiopurine methyltransferase deficient heart transplant recipient. Lancet 341:436
48. Haga SB, Thummel KE, Burke W (2006) Adding pharmacogenetics information to drug labels: lessons learned. Pharmacogenet Genomics 16:847-854

49. Woelderink A, Ibarreta D, Hopkins MM, Rodriguez-Cerezo E (2006) The current clinical practice of pharmacogenetic testing in Europe: TPMT and HER2 as case studies. Pharmacogenomics J $6: 3-7$

50. Van Kuilenburg AB, Vreken $\mathrm{P}$, Abeling NG, Bakker HD, Meinsma R, Van Lenthe H, De Abreu RA, Smeitink JA, Kayserili H, Apak MY, Christensen E, Holopainen I, Pulkki K, Riva D, Botteon G, Holme E, Tulinius M, Kleijer WJ, Beemer FA, Duran M, Niezen-Koning KE, Smit GP, Jakobs C, Smit LM, Van Gennip AH et al (1999) Genotype and phenotype in patients with dihydropyrimidine dehydrogenase deficiency. Hum Genet 104:1-9

51. Harris BE, Carpenter JT, Diasio RB (1991) Severe 5-fluorouracil toxicity secondary to dihydropyrimidine dehydrogenase deficiency. A potentially more common pharmacogenetic syndrome. Cancer 68:499-501

52. Van Kuilenburg AB, Vreken P, Beex LV, Meinsma R, Van Lenthe H, De Abreu RA, van Gennip AH (1997) Heterozygosity for a point mutation in an invariant splice donor site of dihydropyrimidine dehydrogenase and severe 5-fluorouracil related toxicity. Eur J Cancer 33:2258-22564

53. Bosma PJ, Chowdhury JR, Bakker C, Gantla S, de Boer A, Oostra BA, Lindhout D, Tytgat GN, Jansen PL, Oude Elferink RP et al (1995) The genetic basis of the reduced expression of bilirubin UDP-glucuronosyltransferase 1 in Gilbert's syndrome. N Engl J Med 333:1171-1175

54. Hoskins JM, Goldberg RM, Qu P, Ibrahim JG, McLeod HL (2007) UGT1A1*28 Genotype and Irinotecan-Induced Neutropenia: Dose Matters. J Natl Cancer Inst (in press). DOI 10.1093/ jnci/djm 115

55. Seelig A (2007) The role of size and charge for blood-brain barrier permeation of drugs and Fatty acids. J Mol Neurosci 33:32-41

56. Hoffmeyer S, Burk O, von Richter O, Arnold HP, Brockmöller J, Johne A, Cascorbi I, Gerloff T, Roots I, Eichelbaum M, Brinkmann U (2000) Functional polymorphisms of the human multidrug-resistance gene: multiple sequence variations and correlation of one allele with P-glycoprotein expression and activity in vivo. Proc Natl Acad Sci USA 97:3473-3478

57. Chinn LW, Kroetz DL (2007) ABCB1 pharmacogenetics: progress, pitfalls, and promise. Clin Pharmacol Ther 81:265-269

58. Leschziner GD, Andrew T, Pirmohamed M, Johnson MR (2007) $\mathrm{ABCB} 1$ genotype and PGP expression, function and therapeutic drug response: a critical review and recommendations for future research. Pharmacogenom J 7:154-179

59. Tirona RG, Leake BF, Merino G, Kim RB (2001) Polymorphisms in OATP-C: identification of multiple allelic variants associated with altered transport activity among European- and African-Americans. J Biol Chem 276:35669-35675

60. Mwinyi J, Johne A, Bauer S, Roots I, Gerloff T (2004) Evidence for inverse effects of OATP-C (SLC21A6) 5 and 1b haplotypes on pravastatin kinetics. Clin Pharmacol Ther 75:415-421

61. Vormfelde SV, Toliat MR, Schirmer M, Meineke I, Nürnberg P, Brockmöller J (2007) The polymorphisms Asn130Asp and Val174Ala in the organic anion transporting polypeptide OATP1B1 independently affect torsemide pharmacokinetics and -dynamics. Clin Pharmacol Ther (in press)

62. Vormfelde SV, Schirmer M, Hagos Y, Toliat MR, Engelhardt S, Meineke I, Burckhardt G, Nurnberg P, Brockmoller J (2006) Torsemide renal clearance and genetic variation in luminal and basolateral organic anion transporters. $\mathrm{Br} \mathrm{J}$ Clin Pharmacol 62:323-335

63. Shu Y, Sheardown SA, Brown C, Owen RP, Zhang S, Castro RA, Ianculescu AG, Yue L, Lo JC, Burchard EG, Brett CM, 
Giacomini KM (2007) Effect of genetic variation in the organic cation transporter 1 (OCT1) on metformin action. J Clin Invest $117: 1422-1431$

64. Rost S, Fregin A, Ivaskevicius V, Conzelmann E, Hortnagel K, Pelz HJ, Lappegard K, Seifried E, Scharrer I, Tuddenham EG, Muller CR, Strom TM, Oldenburg J (2004) Mutations in VKORC1 cause warfarin resistance and multiple coagulation factor deficiency type 2. Nature 427:537-541

65. Rieder MJ, Reiner AP, Gage BF, Nickerson DA, Eby CS, McLeod HL, Blough DK, Thummel KE, Veenstra DL, Rettie AE (2005) Effect of VKORC1 haplotypes on transcriptional regulation and warfarin dose. N Engl J Med 352:2285-2293

66. Bertina RM, Koeleman BP, Koster T, Rosendaal FR, Dirven RJ, de Ronde H, van der Velden PA, Reitsma PH (1994) Mutation in blood coagulation factor $\mathrm{V}$ associated with resistance to activated protein C. Nature 369:64-67

67. Vandenbroucke JP, van der Meer FJ, Helmerhorst FM, Rosendaal FR (1996) Factor V Leiden: should we screen oral contraceptive users and pregnant women? Br Med J 313:1127-1130

68. Liggett SB (2000) Pharmacogenetics of beta-1- and beta-2adrenergic receptors. Pharmacology 61:167-173

69. Mason DA, Moore JD, Green SA, Liggett SB (1999) A gain-offunction polymorphism in a G-protein coupling domain of the human beta1-adrenergic receptor. J Biol Chem 274:12670-12674

70. Rochais F, Vilardaga JP, Nikolaev VO, Bunemann M, Lohse MJ, Engelhardt S (2007) Real-time optical recording of beta1adrenergic receptor activation reveals supersensitivity of the Arg389 variant to carvedilol. J Clin Invest 117:229-235

71. Brodde OE, Stein CM (2003) The Gly389Arg beta1-adrenergic receptor polymorphism: a predictor of response to beta-blocker treatment? Clin Pharmacol Ther 74:299-302

72. Contopoulos-Ioannidis DG, Kouri I, Ioannidis JPA (2007) Pharmacogenetics of the response to beta2-agnoist drugs: A systematic overview of the field. Pharmacoeconomics 8:933-958

73. Rodriguez-Novoa S, Barreiro P, Jimenez-Nacher I, Soriano V (2006) Overview of the pharmacogenetics of HIV therapy. Pharmacogenomics J 6:234-245

74. Hughes DA, Vilar FJ, Ward CC, Alfirevic A, Park BK, Pirmohamed M (2004) Cost-effectiveness analysis of HLA B*5701 genotyping in preventing abacavir hypersensitivity. Pharmacogenetics 14:335-342

75. Sjoqvist F, Eliasson E (2007) The convergence of conventional therapeutic drug monitoring and pharmacogenetic testing in personalized medicine: focus on antidepressants. Clin Pharmacol Ther 81:899-902

76. Heller T, Kirchheiner J, Armstrong VW, Luthe H, Tzvetkov M, Brockmöller J, Oellerich M (2006) AmpliChip CYP450 GeneChip: a new gene chip that allows rapid and accurate CYP2D6 genotyping. Ther Drug Monit 28:673-677

77. Kirchheiner J, Nickchen K, Bauer M, Wong ML, Licinio J, Roots I, Brockmoller J (2004) Pharmacogenetics of antidepressants and antipsychotics: the contribution of allelic variations to the phenotype of drug response. Mol Psychiatry 9:442-473

78. Kirchheiner J, Schmidt H, Tzvetkov M, Keulen JT, Lotsch J, Roots I, Brockmöller J (2007) Pharmacokinetics of codeine and its metabolite morphine in ultra-rapid metabolizers due to CYP2D6 duplication. Pharmacogenomics J 7:257-265

79. Kirchheiner J, Brøsen K, Dahl ML, Gram LF, Kasper S, Roots I, Sjoqvist F, Spina E, Brockmöller J (2001) CYP2D6 and CYP2C19 genotype-based dose recommendations for antidepressants: a first step towards subpopulation-specific dosages. Acta Psychiatr Scand 104:173-192

80. Caraco Y, Blotnick S, Muszkat M (2007) CYP2C9 genotypeguided warfarin prescribing enhances the efficacy and safety of anticoagulation: a prospective randomized controlled study. Clin Pharmacol Ther (in press). Epub: 12 Sept 2007. PMID: 17851566
81. Hylek EM, Evans-Molina C, Shea C, Henault LE, Regan S (2007) Major hemorrhage and tolerability of warfarin in the first year of therapy among elderly patients with atrial fibrillation. Circulation 115:2689-2696

82. Phillips KA, Van Bebber SL (2004) A systematic review of cost-effectiveness analyses of pharmacogenomic interventions. Pharmacogenomics 5:1139-1149

83. Chou WH, Yan FX, de Leon J, Barnhill J, Rogers T, Cronin M, Pho M, Xiao V, Ryder TB, Liu WW, Teiling C, Wedlund PJ (2000) Extension of a pilot study: impact from the cytochrome P450 2D6 polymorphism on outcome and costs associated with severe mental illness. J Clin Psychopharmacol 20:246-251

84. Ayesh R, Idle JR, Ritchie JC, Crothers MJ, Hetzel MR (1984) Metabolic oxidation phenotypes as markers for susceptibility to lung cancer. Nature 312:169-170

85. Roots I, Drakoulis N, Ploch M, Heinemeyer G, Loddenkemper R, Minks T, Nitz M, Otte F, Koch M (1988) Debrisoquine hydroxylation phenotype, acetylation phenotype, and $\mathrm{ABO}$ blood groups as genetic host factors of lung cancer risk. Klin Wochenschr 66[Suppl 11]:87-97

86. Seidegard J, Vorachek WR, Pero RW, Pearson WR (1988) Hereditary differences in the expression of the human glutathione transferase active on trans-stilbene oxide are due to a gene deletion. Proc Natl Acad Sci USA 85:7293-7297

87. Benhamou S, Lee WJ, Alexandrie AK, Boffetta P, Bouchardy C, Butkiewicz D, Brockmoller J, Clapper ML, Daly A, Dolzan V, Ford J, Gaspari L, Haugen A, Hirvonen A, Husgafvel-Pursiainen K, Ingelman-Sundberg M, Kalina I, Kihara M, Kremers P, Le Marchand L, London SJ, Nazar-Stewart V, Onon-Kihara M, Rannug A, Romkes M, Ryberg D, Seidegard J, Shields P, Strange RC, Stucker I, To-Figueras J, Brennan P, Taioli E (2002) Meta- and pooled analyses of the effects of glutathione Stransferase M1 polymorphisms and smoking on lung cancer risk. Carcinogenesis 23:1343-1350

88. Spinola M, Meyer P, Kammerer S, Falvella FS, Boettger MB, Hoyal CR, Pignatiello C, Fischer R, Roth RB, Pastorino U, Haeussinger K, Nelson MR, Dierkesmann R, Dragani TA, Braun A (2006) Association of the PDCD5 locus with lung cancer risk and prognosis in smokers. J Clin Oncol 24:1672-1678

89. Levy S, Sutton G, Ng PC, Feuk L, Halpern AL, Walenz BP, Axelrod N, Huang J, Kirkness EF, Denisov G, Lin Y, Macdonald JR, Pang AW, Shago M, Stockwell TB, Tsiamouri A, Bafna V, Bansal V, Kravitz SA, Busam DA, Beeson KY, McIntosh TC, Remington KA, Abril JF, Gill J, Borman J, Rogers YH, Frazier ME, Scherer SW, Strausberg RL, Venter JC (2007) The diploid genome sequence of an individual human. PLoS Biol 5:e254

90. The International HapMap Consortium (2005) A haplotype map of the human genome. Nature 437:1299-320

91. Eckhardt F, Lewin J, Cortese R, Rakyan VK, Attwood J, Burger M, Burton J, Cox TV, Davies R, Down TA, Haefliger C, Horton R, Howe K, Jackson DK, Kunde J, Koenig C, Liddle J, Niblett D, Otto T, Pettett R, Seemann S, Thompson C, West T, Rogers J, Olek A, Berlin K, Beck S (2006) DNA methylation profiling of human chromosomes 6, 20 and 22. Nat Genet 38:1378-1385

92. Redon R, Ishikawa S, Fitch KR, Feuk L, Perry GH, Andrews TD, Fiegler H, Shapero MH, Carson AR, Chen W, Cho EK, Dallaire S, Freeman JL, Gonzalez JR, Gratacos M, Huang J, Kalaitzopoulos D, Komura D, MacDonald JR, Marshall CR, Mei R, Montgomery L, Nishimura K, Okamura K, Shen F, Somerville MJ, Tchinda J, Valsesia A, Woodwark C, Yang F, Zhang J, Zerjal T, Zhang J, Armengol L, Conrad DF, Estivill X, Tyler-Smith C, Carter NP, Aburatani H, Lee C, Jones KW, Scherer SW, Hurles ME (2006) Global variation in copy number in the human genome. Nature 444:444-454

93. Kaiser R, Konneker M, Henneken M, Dettling M, MullerOerlinghausen B, Roots I, Brockmoller J (2000) Dopamine D4 
receptor 48-bp repeat polymorphism: no association with response to antipsychotic treatment, but association with catatonic schizophrenia. Mol Psychiatry 5:418-424

94. Tzvetkov MV, Meineke C, Oetjen E, Hirsch-Ernst K, Brockmoller J (2007) Tissue-specific alternative promoters of the serotonin receptor gene HTR3B in human brain and intestine. Gene 386:52-62

95. Kimchi-Sarfaty C, Oh JM, Kim IW, Sauna ZE, Calcagno AM, Ambudkar SV, Gottesman MM (2007) A "silent" polymorphism in the MDR1 gene changes substrate specificity. Science 315:525-528

96. Conrad DF, Andrews TD, Carter NP, Hurles ME, Pritchard JK (2006) A high-resolution survey of deletion polymorphism in the human genome. Nat Genet 38:75-81

97. Hinds DA, Kloek AP, Jen M, Chen X, Frazer KA (2006) Common deletions and SNPs are in linkage disequilibrium in the human genome. Nat Genet 38:82-85

98. Khaja R, Zhang J, MacDonald JR, He Y, Joseph-George AM, Wei J, Rafiq MA, Qian C, Shago M, Pantano L, Aburatani H, Jones K, Redon R, Hurles M, Armengol L, Estivill X, Mural RJ, Lee C, Scherer SW, Feuk L (2006) Genome assembly comparison identifies structural variants in the human genome. Nat Genet 38:1413-1418

99. McCarroll SA, Hadnott TN, Perry GH, Sabeti PC, Zody MC, Barrett JC, Dallaire S, Gabriel SB, Lee C, Daly MJ, Altshuler DM (2006) Common deletion polymorphisms in the human genome. Nat Genet 38:86-92

100. Wong KK, deLeeuw RJ, Dosanjh NS, Kimm LR, Cheng Z, Horsman DE, MacAulay C, Ng RT, Brown CJ, Eichler EE, Lam WL (2007) A comprehensive analysis of common copy-number variations in the human genome. Am J Hum Genet 80:91-104

101. Beckmann JS, Estivill X, Antonarakis SE (2007) Copy number variants and genetic traits: closer to the resolution of phenotypic to genotypic variability. Nat Rev Genet 8:639-646

102. Pemble S, Schroeder KR, Spencer SR, Meyer DJ, Hallier E, Bolt HM, Ketterer B, Taylor JB (1994) Human glutathione Stransferase theta (GSTT1): cDNA cloning and the characterization of a genetic polymorphism. Biochem J 300:271-276

103. Schaeffeler E, Schwab M, Eichelbaum M, Zanger UM (2003) CYP2D6 genotyping strategy based on gene copy number determination by TaqMan real-time PCR. Hum Mutat 22:476-485

104. Sprenger R, Schlagenhaufer R, Kerb R, Bruhn C, Brockmoller J, Roots I, Brinkmann U (2000) Characterization of the glutathione S-transferase GSTT1 deletion: discrimination of all genotypes by polymerase chain reaction indicates a trimodular genotypephenotype correlation. Pharmacogenetics 10:557-565

105. Cheng Q, Yang W, Raimondi SC, Pui CH, Relling MV, Evans WE (2005) Karyotypic abnormalities create discordance of germline genotype and cancer cell phenotypes. Nat Genet 37:878-882

106. Stanulla M, Schaeffeler E, Flohr T, Cario G, Schrauder A, Zimmermann M, Welte K, Ludwig WD, Bartram CR, Zanger UM, Eichelbaum M, Schrappe M, Schwab M (2005) Thiopurine methyltransferase (TPMT) genotype and early treatment response to mercaptopurine in childhood acute lymphoblastic leukemia. JAMA 293:1485-1489

107. Dolinoy DC (2007) Epigenetic gene regulation: early environmental exposures. Pharmacogenomics 8:5-10

108. Collie-Duguid ES, Etienne MC, Milano G, McLeod HL (2000) Known variant DPYD alleles do not explain DPD deficiency in cancer patients. Pharmacogenetics 10:217-223

109. van Kuilenburg AB, Muller EW, Haasjes J, Meinsma R, Zoetekouw L, Waterham HR, Baas F, Richel DJ, van Gennip AH (2001) Lethal outcome of a patient with a complete dihydropyrimidine dehydrogenase (DPD) deficiency after administration of 5-fluorouracil: frequency of the common IVS14+1G $>$ A mutation causing DPD deficiency. Clin Cancer Res 7:1149-1153
110. Ezzeldin HH, Lee AM, Mattison LK, Diasio RB (2005) Methylation of the DPYD promoter: an alternative mechanism for dihydropyrimidine dehydrogenase deficiency in cancer patients. Clin Cancer Res 11:8699-8705

111. Noguchi T, Tanimoto K, Shimokuni T, Ukon K, Tsujimoto H, Fukushima M, Noguchi T, Kawahara K, Hiyama K, Nishiyama M (2004) Aberrant methylation of DPYD promoter, DPYD expression, and cellular sensitivity to 5-fluorouracil in cancer cells. Clin Cancer Res 10:7100-7107

112. Yu J, Shannon WD, Watson MA, McLeod HL (2005) Gene expression profiling of the irinotecan pathway in colorectal cancer. Clin Cancer Res 11:2053-2062

113. Zhang X, Soong R, Wang K, Li L, Davie JR, Guarcello V, Diasio RB (2007) Suppression of DPYD expression in RKO cells via DNA methylation in the regulatory region of the DPYD promoter: a potentially important epigenetic mechanism regulating DPYD expression. Biochem Cell Biol 85:337-346

114. Esteller M, Garcia-Foncillas J, Andion E, Goodman SN, Hidalgo OF, Vanaclocha V, Baylin SB, Herman JG (2000) Inactivation of the DNA-repair gene MGMT and the clinical response of gliomas to alkylating agents. N Engl J Med 343:1350-1354

115. Lee RC, Feinbaum RL, Ambros V (1993) The C. elegans heterochronic gene lin-4 encodes small RNAs with antisense complementarity to lin-14. Cell 75:843-854

116. Calin GA, Ferracin M, Cimmino A, Di Leva G, Shimizu M, Wojcik SE, Iorio MV, Visone R, Sever NI, Fabbri M, Iuliano R, Palumbo T, Pichiorri F, Roldo C, Garzon R, Sevignani C, Rassenti L, Alder H, Volinia S, Liu CG, Kipps TJ, Negrini M, Croce CM (2005) A MicroRNA signature associated with prognosis and progression in chronic lymphocytic leukemia. $\mathrm{N}$ Engl J Med 353:1793-1801

117. Schier AF (2007) The maternal-zygotic transition: death and birth of RNAs. Science 316:406-407

118. Sethupathy P, Borel C, Gagnebin M, Grant GR, Deutsch S, Elton TS, Hatzigeorgiou AG, Antonarakis SE (2007) Human microRNA- 155 on chromosome 21 differentially interacts with its polymorphic target in the AGTR1 3' untranslated region: a mechanism for functional single-nucleotide polymorphisms related to phenotypes. Am J Hum Genet 81:405-413

119. Dorsett Y, Tuschl T (2004) siRNAs: applications in functional genomics and potential as therapeutics. Nat Rev Drug Discov $3: 318-329$

120. Feng X, Zhao P, He Y, Zuo Z (2006) Allele-specific silencing of Alzheimer's disease genes: the amyloid precursor protein genes with Swedish or London mutations. Gene 371:68-74

121. Gonzalez-Alegre P, Bode N, Davidson BL, Paulson HL (2005) Silencing primary dystonia: lentiviral-mediated RNA interference therapy for DYT1 dystonia. J Neurosci 25:10502-10509

122. Miller VM, Xia H, Marrs GL, Gouvion CM, Lee G, Davidson BL, Paulson HL (2003) Allele-specific silencing of dominant disease genes. Proc Natl Acad Sci USA 100:7195-7200

123. Xia X, Zhou H, Huang Y, Xu Z (2006) Allele-specific RNAi selectively silences mutant SOD1 and achieves significant therapeutic benefit in vivo. Neurobiol Dis 23:578-586

124. Rodriguez-Lebron E, Paulson HL (2006) Allele-specific RNA interference for neurological disease. Gene Ther 13:576-581

125. Carlson RW, Moench SJ, Hammond ME, Perez EA, Burstein HJ, Allred DC, Vogel CL, Goldstein LJ, Somlo G, Gradishar WJ, Hudis CA, Jahanzeb M, Stark A, Wolff AC, Press MF, Winer EP, Paik S, Ljung BM (2006) HER2 testing in breast cancer: NCCN Task Force report and recommendations. J Natl Compr Canc Netw 4[Suppl 3]:S1-S22

126. Schnitt SJ (2006) Estrogen receptor testing of breast cancer in current clinical practice: what's the question? J Clin Oncol 24:1797-1799 
127. Lamy PJ, Nanni I, Fina F, Bibeau F, Romain S, Dussert C, Penault Llorca F, Grenier J, Ouafik LH, Martin PM (2006) Reliability and discriminant validity of HER2 gene quantification and chromosome 17 aneusomy analysis by real-time PCR in primary breast cancer. Int J Biol Markers 21:20-29

128. Savino M, Garrubba M, Parrella P, Baorda F, Copetti M, Murgo R, Zelante L, Carella M, Valori VM, Santini SA (2007) Development of real-time quantitative reverse transcriptionPCR for Her2 detection in peripheral blood from patients with breast cancer. Clin Chim Acta 384:52-56

129. Tse C, Brault D, Gligorov J, Antoine M, Neumann R, Lotz JP, Capeau J (2005) Evaluation of the quantitative analytical methods real-time PCR for HER-2 gene quantification and ELISA of serum HER-2 protein and comparison with fluorescence in situ hybridization and immunohistochemistry for determining HER-2 status in breast cancer patients. Clin Chem 51:1093-1101

130. Chu I, Arnaout A, Loiseau S, Sun J, Seth A, McMahon C, Chun K, Hennessy B, Mills GB, Nawaz Z, Slingerland JM (2007) Src promotes estrogen-dependent estrogen receptor alpha proteolysis in human breast cancer. J Clin Invest 117:2205-2215

131. Cheok MH, Evans WE (2006) Acute lymphoblastic leukaemia: a model for the pharmacogenomics of cancer therapy. Nat Rev Cancer 6:117-129

132. Joyce T, Pintzas A (2007) Microarray analysis to reveal genes involved in colon carcinogenesis. Expert Opin Pharmacother 8:895-900

133. Miller LD, Liu ET (2007) Expression genomics in breast cancer research: microarrays at the crossroads of biology and medicine. Breast Cancer Res 9:206

134. Ronaghi M, Karamohamed S, Pettersson B, Uhlen M, Nyren P (1996) Real-time DNA sequencing using detection of pyrophosphate release. Anal Biochem 242:84-89

135. Margulies M, Egholm M, Altman WE, Attiya S, Bader JS, Bemben LA, Berka J, Braverman MS, Chen YJ, Chen Z, Dewell SB, Du L, Fierro JM, Gomes XV, Godwin BC, He W, Helgesen $\mathrm{S}$, Ho CH, Irzyk GP, Jando SC, Alenquer ML, Jarvie TP, Jirage KB, Kim JB, Knight JR, Lanza JR, Leamon JH, Lefkowitz SM, Lei M, Li J, Lohman KL, Lu H, Makhijani VB, McDade KE, McKenna MP, Myers EW, Nickerson E, Nobile JR, Plant R, Puc BP, Ronan MT, Roth GT, Sarkis GJ, Simons JF, Simpson JW, Srinivasan M, Tartaro KR, Tomasz A, Vogt KA, Volkmer GA, Wang SH, Wang Y, Weiner MP, Yu P, Begley RF, Rothberg JM (2005) Genome sequencing in microfabricated high-density picolitre reactors. Nature 437:376-380

136. Daly AK, Brockmöller J, Broly F, Eichelbaum M, Evans WE, Gonzalez FJ, Huang JD, Idle JR, Ingelman-Sundberg M, Ishizaki T, Jacqz-Aigrain E, Meyer UA, Nebert DW, Steen VM, Wolf CR, Zanger UM (1996) Nomenclature for human CYP2D6 alleles. Pharmacogenetics 6:193-201

137. Marchini J, Howie B, Myers S, McVean G, Donnelly P (2007) A new multipoint method for genome-wide association studies by imputation of genotypes. Nat Genet 39:906-913

138. Thorisson GA, Smith AV, Krishnan L, Stein LD (2005) The International HapMap Project Web site. Genome Res 15:15921593

139. Barrett JC, Fry B, Maller J, Daly MJ (2005) Haploview: analysis and visualization of $\mathrm{LD}$ and haplotype maps. Bioinformatics 21:263-265

140. Warren LL, Hughes AR, Lai EH, Zaykin DV, Haneline SA, Bansal AT, Wooster AW, Spreen WR, Hernandez JE, Scott TR, Roses AD, Mosteller M (2007) Use of pairwise marker combination and recursive partitioning in a pharmacogenetic genome-wide scan. Pharmacogenomics J 7:180-189

141. Kulle B, Schirmer M, Toliat MR, Suk A, Becker C, Tzvetkov MV, Brockmoller J, Bickeboller H, Hasenfuss G, Nurnberg P, Wojnowski L (2005) Application of genomewide SNP arrays for detection of simulated susceptibility loci. Hum Mutat 25:557565

142. Klein RJ, Zeiss C, Chew EY, Tsai JY, Sackler RS, Haynes C, Henning AK, SanGiovanni JP, Mane SM, Mayne ST, Bracken MB, Ferris FL, Ott J, Barnstable C, Hoh J (2005) Complement factor $\mathrm{H}$ polymorphism in age-related macular degeneration. Science 308:385-389

143. Edwards AO, Ritter R 3rd, Abel KJ, Manning A, Panhuysen C, Farrer LA (2005) Complement factor $\mathrm{H}$ polymorphism and agerelated macular degeneration. Science 308:421-424

144. Haines JL, Hauser MA, Schmidt S, Scott WK, Olson LM, Gallins P, Spencer KL, Kwan SY, Noureddine M, Gilbert JR, Schnetz-Boutaud N, Agarwal A, Postel EA, Pericak-Vance MA (2005) Complement factor $\mathrm{H}$ variant increases the risk of agerelated macular degeneration. Science 308:419-421

145. Abecasis GR, Yashar BM, Zhao Y, Ghiasvand NM, Zareparsi S, Branham KE, Reddick AC, Trager EH, Yoshida S, Bahling J, Filippova E, Elner S, Johnson MW, Vine AK, Sieving PA, Jacobson SG, Richards JE, Swaroop A (2004) Age-related macular degeneration: a high-resolution genome scan for susceptibility loci in a population enriched for late-stage disease. Am J Hum Genet 74:482-494

146. Weeks DE, Conley YP, Tsai HJ, Mah TS, Schmidt S, Postel EA, Agarwal A, Haines JL, Pericak-Vance MA, Rosenfeld PJ, Paul TO, Eller AW, Morse LS, Dailey JP, Ferrell RE, Gorin MB (2004) Age-related maculopathy: a genomewide scan with continued evidence of susceptibility loci within the 1q31, 10q26, and 17q25 regions. Am J Hum Genet 75:174-189

147. Thorleifsson G, Magnusson KP, Sulem P, Walters GB, Gudbjartsson DF, Stefansson H, Jonsson T, Jonasdottir A, Jonasdottir A, Stefansdottir G, Masson G, Hardarson GA, Petursson H, Arnarsson A, Motallebipour M, Wallerman O, Wadelius C, Gulcher JR, Thorsteinsdottir U, Kong A, Jonasson F, Stefansson K (2007) Common sequence variants in the LOXL1 gene confer susceptibility to exfoliation glaucoma. Science 317:1397-1400

148. Buch S, Schafmayer C, Volzke H, Becker C, Franke A, von Eller-Eberstein H, Kluck C, Bassmann I, Brosch M, Lammert F, Miquel JF, Nervi F, Wittig M, Rosskopf D, Timm B, Holl C, Seeger M, ElSharawy A, Lu T, Egberts J, Fandrich F, Folsch UR, Krawczak M, Schreiber S, Nurnberg P, Tepel J, Hampe J (2007) A genome-wide association scan identifies the hepatic cholesterol transporter ABCG8 as a susceptibility factor for human gallstone disease. Nat Genet 39:995-999

149. he Wellcome Trust Case Control Consortium (2007) Genomewide association study of 14,000 cases of seven common diseases and 3,000 shared controls. Nature 447:661-678

150. Helgadottir A, Thorleifsson G, Manolescu A, Gretarsdottir S, Blondal T, Jonasdottir A, Jonasdottir A, Sigurdsson A, Baker A, Palsson A, Masson G, Gudbjartsson DF, Magnusson KP, Andersen K, Levey AI, Backman VM, Matthiasdottir S, Jonsdottir T, Palsson S, Einarsdottir H, Gunnarsdottir S, Gylfason A, Vaccarino V, Hooper WC, Reilly MP, Granger CB, Austin H, Rader DJ, Shah SH, Quyyumi AA, Gulcher JR, Thorgeirsson G, Thorsteinsdottir U, Kong A, Stefansson K (2007) A common variant on chromosome 9p21 affects the risk of myocardial infarction. Science 316:1491-1493

151. Gudbjartsson DF, Arnar DO, Helgadottir A, Gretarsdottir S, Holm H, Sigurdsson A, Jonasdottir A, Baker A, Thorleifsson G, Kristjansson K, Palsson A, Blondal T, Sulem P, Backman VM, Hardarson GA, Palsdottir E, Helgason A, Sigurjonsdottir R, Sverrisson JT, Kostulas K, Ng MC, Baum L, So WY, Wong KS, Chan JC, Furie KL, Greenberg SM, Sale M, Kelly P, MacRae CA, Smith EE, Rosand J, Hillert J, Ma RC, Ellinor PT, Thorgeirsson G, Gulcher JR, Kong A, Thorsteinsdottir U, Stefansson K (2007) Variants conferring risk of atrial fibrillation on chromosome 4q25. Nature 448:353-357 
152. Saxena R, Voight BF, Lyssenko V, Burtt NP, de Bakker PI, Chen H, Roix JJ, Kathiresan S, Hirschhorn JN, Daly MJ, Hughes TE, Groop L, Altshuler D, Almgren P, Florez JC, Meyer J, Ardlie K, Bengtsson Bostrom $\mathrm{K}$, Isomaa $\mathrm{B}$, Lettre $\mathrm{G}$, Lindblad U, Lyon HN, Melander O, Newton-Cheh C, Nilsson P, Orho-Melander M, Rastam L, Speliotes EK, Taskinen MR, Tuomi T, Guiducci C, Berglund A, Carlson J, Gianniny L, Hackett R, Hall L, Holmkvist J, Laurila E, Sjogren M, Sterner M, Surti A, Svensson M, Svensson M, Tewhey R, Blumenstiel B, Parkin M, Defelice M, Barry R, Brodeur W, Camarata J, Chia N, Fava M, Gibbons J, Handsaker B, Healy C, Nguyen K, Gates C, Sougnez C, Gage D, Nizzari M, Gabriel SB, Chirn GW, Ma Q, Parikh H, Richardson D, Ricke D, Purcell S (2007) Genome-wide association analysis identifies loci for type 2 diabetes and triglyceride levels. Science 316:1331-1336

153. Plenge RM, Seielstad M, Padyukov L, Lee AT, Remmers EF, Ding B, Liew A, Khalili H, Chandrasekaran A, Davies LR, Li W, Tan AK, Bonnard C, Ong RT, Thalamuthu A, Pettersson S, Liu C, Tian C, Chen WV, Carulli JP, Beckman EM, Altshuler D, Alfredsson L, Criswell LA, Amos CI, Seldin MF, Kastner DL, Klareskog L, Gregersen PK (2007) TRAF1-C5 as a risk locus for rheumatoid arthritis-a genomewide study. N Engl J Med 357:1199-209

154. Easton DF, Pooley KA, Dunning AM, Pharoah PD, Thompson D, Ballinger DG, Struewing JP, Morrison J, Field H, Luben R, Wareham N, Ahmed S, Healey CS, Bowman R, Meyer KB, Haiman CA, Kolonel LK, Henderson BE, Le Marchand L, Brennan P, Sangrajrang S, Gaborieau V, Odefrey F, Shen CY, Wu PE, Wang HC, Eccles D, Evans DG, Peto J, Fletcher O, Johnson N, Seal S, Stratton MR, Rahman N, Chenevix-Trench G, Bojesen SE, Nordestgaard BG, Axelsson CK, Garcia-Closas M, Brinton L, Chanock S, Lissowska J, Peplonska B, Nevanlinna H, Fagerholm R, Eerola H, Kang D, Yoo KY, Noh DY, Ahn SH, Hunter DJ, Hankinson SE, Cox DG, Hall P, Wedren S, Liu J, Low YL, Bogdanova N, Schurmann P, Dork T, Tollenaar RA, Jacobi CE, Devilee P, Klijn JG, Sigurdson AJ, Doody MM, Alexander BH, Zhang J, Cox A, Brock IW, MacPherson G, Reed MW, Couch FJ, Goode EL, Olson JE, Meijers-Heijboer H, van den Ouweland A, Uitterlinden A, Rivadeneira F, Milne RL, Ribas G, Gonzalez-Neira A, Benitez J, Hopper JL, McCredie M, Southey M, Giles GG, Schroen C, Justenhoven C, Brauch H, Hamann U, Ko YD, Spurdle AB, Beesley J, Chen X, Mannermaa A, Kosma VM, Kataja V, Hartikainen J, Day NE, Cox DR, Ponder BA (2007) Genome-wide association study identifies novel breast cancer susceptibility loci. Nature 447:1087-1093
155. Tomlinson I, Webb E, Carvajal-Carmona L, Broderick P, Kemp Z, Spain S, Penegar S, Chandler I, Gorman M, Wood W, Barclay E, Lubbe S, Martin L, Sellick G, Jaeger E, Hubner R, Wild R, Rowan A, Fielding S, Howarth K, Silver A, Atkin W, Muir K, Logan R, Kerr D, Johnstone E, Sieber O, Gray R, Thomas H, Peto J, Cazier JB, Houlston R (2007) A genome-wide association scan of tag SNPs identifies a susceptibility variant for colorectal cancer at 8q24.21. Nat Genet 39:984-988

156. Huang Y (2007) Pharmacogenetics/genomics of membrane transporters in cancer chemotherapy. Cancer Metastasis Rev 26:183-201

157. Kuivenhoven JA, Jukema JW, Zwinderman AH, de Knijff P, McPherson R, Bruschke AV, Lie KI, Kastelein JJ (1998) The role of a common variant of the cholesteryl ester transfer protein gene in the progression of coronary atherosclerosis. The Regression Growth Evaluation Statin Study Group. N Engl J Med 338:86-93

158. Zeggini E, Weedon MN, Lindgren CM, Frayling TM, Elliott KS, Lango H, Timpson NJ, Perry JR, Rayner NW, Freathy RM, Barrett JC, Shields B, Morris AP, Ellard S, Groves CJ, Harries LW, Marchini JL, Owen KR, Knight B, Cardon LR, Walker M, Hitman GA, Morris AD, Doney AS, McCarthy MI, Hattersley AT (2007) Replication of genome-wide association signals in UK samples reveals risk loci for type 2 diabetes. Science 316:1336-1341

159. Brockmoller J, Cascorbi I, Henning S, Meisel C, Roots I (2000) Molecular genetics of cancer susceptibility. Pharmacology 61:212-227

160. Serretti A, Kato M, Kennedy JL (2007) Pharmacogenetic studies in depression: a proposal for methodologic guidelines. Pharmacogenomics $\mathrm{J}$

161. Chanock SJ, Manolio T, Boehnke M, Boerwinkle E, Hunter DJ, Thomas G, Hirschhorn JN, Abecasis G, Altshuler D, BaileyWilson JE, Brooks LD, Cardon LR, Daly M, Donnelly P, Fraumeni JF Jr, Freimer NB, Gerhard DS, Gunter C, Guttmacher AE, Guyer MS, Harris EL, Hoh J, Hoover R, Kong CA, Merikangas KR, Morton CC, Palmer LJ, Phimister EG, Rice JP, Roberts J, Rotimi C, Tucker MA, Vogan KJ, Wacholder S, Wijsman EM, Winn DM, Collins FS (2007) Replicating genotype-phenotype associations. Nature 447:655-660

162. Shukla SJ, Dolan ME (2005) Use of CEPH and non-CEPH lymphoblast cell lines in pharmacogenetic studies. Pharmacogenomics 6:303-310

163. Shah RR (2005) Drug-induced QT interval prolongationregulatory guidance and perspectives on $\mathrm{hERG}$ channel studies. Novartis Found Symp 266:251-280 discussion 280-285

164. Merikangas KR, Risch N (2003) Genomic priorities and public health. Science 302:599-601 